\title{
Contract Flexibility and Dispute Resolution in African Manufacturing
}

\author{
Arne Bigsten, Paul Collier, Stefan Dercon, Marcel Fafchamps, \\ Bernard Gauthier, Jan Willem Gunning, Abena Oduro, Remco Oostendorp, \\ Cathy Patillo, Mans Soderbom, Francis Teal, and Albert Zeufack. ${ }^{1}$
}

Last revised in August 1999

WPS-9920

\begin{abstract}
This paper examines the contractual practices of African manufacturing firms using survey data collected in Burundi, Cameroon, Côte d'Ivoire, Kenya, Zambia, and Zimbabwe. Descriptive statistics and econometric results are presented. They show that contractual flexibility is pervasive and that relational contracting is the norm between manufacturers, their suppliers, and their clients. The existence of long-term relations between firms helps them deal with contract non-performance through negotiation. Confrontational methods such as lawyers and courts are used only by large firms and when negotiations fail. Whenever confrontation can be avoided, business is resumed. Of the six studied countries, incidence of breach and the use of lawyers and courts are highest in Zimbabwe which is also the country with legal institutions that best support business. Our favored interpretation is that good legal institutions incite firms to take more chances, thereby encouraging trade and leading to more cases of breach and more recourse to courts and lawyers. A high frequency of contract non-compliance should thus not be interpreted as a sign of imperfect legal institutions.
\end{abstract}

\footnotetext{
1 Correspondence to be sent to Marcel Fafchamps, Center for the Study of African Economies, University of Oxford, Manor Road, Oxford OX1 3UL (United Kingdom). Email: marcel.fafchamps@economics.ox.ac.uk.
} 
This paper investigates the contractual practices of African manufacturing firms and examines whether economic agents use long-term relationships to make contractual performance contingent upon external shocks. Evidence to this effect has already been uncovered in credit transactions among villagers (e.g., Udry (1990, 1994), Fafchamps and Lund (1999)) and fishermen (e.g., Platteau and Abraham (1987)). In contrast to these earlier works that focused on small individual transactions in a rural setting, this paper analyzes the extent of contractual flexibility among large manufacturing firms.

Very little is known about how African markets operate in practice. Fafchamps et al. (1994), Fafchamps, Pender and Robinson (1995), and Fafchamps (1996) have shown that contracts between African manufacturers and their suppliers and clients often are renegotiated: supplies occasionally arrive late or their quality is different from what was ordered, and clients sometimes pay late. Although some modicum of contractual flexibility is prevalent the world over, casual observation and anthropological accounts (e.g., Cohen (1969), Meillassoux (1971), Amselle (1977), Geertz, Geertz and Rosen (1979)) suggest that African firms have a more elastic definition of flexibility -- to the point where it may have become a source of misunderstanding and cultural prejudice. In their dealings with Africans, for instance, foreigners are often taken by surprise by contractual delays and calls for contractual renegotiation, from which they are quick to conclude that African firms (and Africans in general) are unreliable and opportunistic. This is true not only of the occasional traveller, but also of western firms wishing to source products from Africa (e.g., Biggs et al. (1994)). This may explain why foreign firms find it difficult to deal with Africans and why African manufacturers have a hard time breaking into export markets. If confirmed by rigorous analysis, this interpretation opens avenues for export promotion other than structural adjustment and devaluation.

This paper examines evidence on contractual flexibility among African manufacturing firms using data collected in six countries: Burundi, Cameroon, Côte d'Ivoire, Kenya, Zambia, and Zimbabwe. The empirical analysis tests simple theoretical predictions regarding the incidence of contractual problems and the way contractual disputes are resolved. Results provide the first empirical evidence regarding the extent of and local remedies to contractual nonperformance in African manufacturing. They now need to be compared with contractual practices in other parts of the world.

Our results are consistent with the idea that contractual flexibility is a rational response to risk. Expectations regarding contractual performance are thus likely to reflect the environment in which firms operate: the riskier the environment, the higher the need for flexibility, the higher the incidence of contract non-performance, and the higher the expectation of renegotiation. Results also show that, of the six countries studied, incidence of breach and the use of lawyers and courts are highest in Zimbabwe. Since Zimbabwe is probably the country in the sample where legal institutions best support business (e.g., Fafchamps, Pender and Robinson (1995)), this finding contradicts the idea that a high frequency of contract non-compliance is a sign of imperfect legal institutions and unsophisticated business practices. We similarly find that large firms are both more likely to encounter contract non-compliance and to make use of lawyers and courts. Taken together, these results suggest that access to supportive legal institutions incite firms to take more chances with suppliers and clients, thereby encouraging trade while at the same time resulting in more cases of breach and more recourse to courts and lawyers. In contrast, firms that have little or no access to courts must rely on alternative institutions such as business relationships and social networks, and adopt cruder business practices to minimize their exposure to contractual risk (e.g., Fafchamps (1999b, 1999c)). Similar conclusions are reached by Fafchamps and Minten (1999b).

The paper is organized as follows. Section 1 presents a brief review of the theoretical literature on markets and contractual flexibility. Descriptive evidence on African manufacturers is presented in Section 2. Detailed econometric analysis is discussed in Section 3. 


\section{Section 1. A Brief Review of Theory}

The last two decades have witnessed a world-wide renewed faith in the capacity of market forces to allocate resources efficiently. Governments have been advised to stop meddling in the allocation process and to let the 'free market' reign. Very little, however, is know as to how a free market actually operates in practice. In particular, we know precious little about how firms deal with each other. For instance, it is unclear how firms which otherwise compete with each other and have opposed interests manage to prevent opportunistic breach of contract. Yet if the market is to do a better resource allocation job than the government, then surely it must deter or at least minimize cheating among economic agents.

\section{Markets and Opportunism}

Microeconomic textbooks depict market transactions as simple exchanges whose economic content is fully described by price and quantity. Evidence collected in Africa and elsewhere suggests otherwise. Purchases of inputs and sales of output -- let alone the provision of labor or credit -- are plagued by a variety of moral hazard, adverse selection, and contract enforcement problems that shape economic exchange and determine how efficient markets are (on African manufacturing, see for instance the empirical evidence reported by Fafchamps (1996), Fisman and Raturi (1999), Raturi and Swamy (1999), Fafchamps and Minten (1999a, 1999b)). Before we can progress in our understanding of how African markets work in practice, we need a theory of market exchange that can account for these features.

In this respect, recent theoretical developments provide a fertile source of inspiration. Building upon the work of Kranton (1996a) and Ghosh and Ray (1996), Fafchamps (1998) formally shows that a decentralized market can discipline itself if cheating is interpreted as a sign of incompetence. The mechanism by which opportunism is deterred, however, leads to markets that differ significantly from those described in economic textbooks. For one thing, exchange is not anonymous but relational: firms economize on screening incompetent partners by establishing long-term relationships with other firms they have learn to trust. As in Shapiro and Stiglitz's (1984) model of unemployment as a disciplining device, cheating by competent agents is deterred by the fear of having to search for a new partner.

Relational contracting is, however, an impediment to fully efficient exchange because it makes it costly for firms to switch partners. This may be alright in stable economic environments in which patterns of exchange are constant over time. But if firms must respond to rapidly changing economic conditions by constantly seeking new partners, being stuck with the same partner forever is not optimal. In this case, Greif (1993) and Fafchamps (1998) have shown that information sharing can theoretically increase the fluidity of exchange by reducing the penalty for switching partner. ${ }^{2}$

The above mentioned work suffers from one major shortcoming, however: it assumes that cheating is a cut and dry affair, i.e., that firms can always honor their contractual obligations, and that the only problem is to ensure they do. In real life, however, circumstances arise in which firms are unable to comply with a contract: a power outage may delay production, civil strife may interfere with delivery, or the central bank may not release the foreign exchange on time. The circumstances that impede contractual performance may be temporary or permanent. If they are temporary, it would be silly to destroy a perfectly good relationship simply because one of the partners is temporarily unable to perform. Intuitively, it is in the interest of the two parties to work things out until the difficulty is over. Fafchamps (1996) indeed demonstrates theoretically that if there are exogenous circumstances in which one party, say $A$, is unable to comply with its contractual obligations, then it is not in the interest of the other party $B$ to insist on harsh punishment for breach of contract. Doing so would only incite $A$ to refuse to trade ex ante. ${ }^{3}$

\footnotetext{
2 To achieve this purpose, however, the stigmatization of cheaters may be necessary; see Milgrom, North and Weingast (1991) and Fafchamps (1998) for details. Firms may also seek to economize on screening costs by relying on statistical discrimination or by refusing to deal with firms outside their network. Empirical evidence on these issues is presented in Greif (1994) and Fafchamps (1999a).

3 To see why, consider the following caricatural example. Suppose a bank proposes to lend you one million dollars free of interest but stipulates that, in case the money is not repaid in full by a given date, you will be executed. To the
} 
In this case, theory suggests that it is optimal for the parties to recognize that exogenous circumstances may prevent them from honoring their obligations and to build flexibility into the contract. When exchange is relational, flexibility is facilitated by the implicit agreement that binds the parties: if one party feels cheated, it can decide to break the relationship and force the other party to look for another supplier or client. In addition, the aggrieved party may seek reparation by enlisting the help of an external contract enforcement agency. The existence of an implicit threat to seek outside reparation only if trust has been broken helps the parties to economize on writing the contract. There is no need to write all contingencies down; all that is required is that parties apply the contract in good faith, that is, to the best of their capacity. These theoretical arguments are clear and have been formalized elsewhere (e.g., Hart and Holmstrom (1987), Fafchamps (1996)). What is unclear is whether they are relevant at all in practice.

\section{Contract Flexibility}

Evidence suggests that market transactions, far from being rigid contracts, exhibit an unexpected degree of flexibility (e.g., Lorenz (1988) for France, and Fafchamps (1996), Fafchamps, Pender and Robinson (1995) for Africa). To fully understand how markets operate in practice, we need to conceptually understand what flexibility means and why it exists. Flexibility arises when contractual performance is made explicitly or implicitly contingent upon external events affecting one of the parties. The idea is that a supplier who cannot deliver or client who cannot pay is allowed to renegotiate the contract and default from his or her original obligations. Flexibility is thus a form of insurance, of risk sharing.

Fafchamps (1996) has argued that, from a theoretical perspective, economic exchange cannot take place unless contract are flexible. This is because parties can never to totally sure they can comply with their contractual obligations: external events may prevent them from doing so. Unless they can exonerate themselves from obligations that have become too onerous, they will refuse to engage themselves.

Allowing parties too much flexibility, however, is opening room for much abuse. Contractual obligations must therefore be sufficiently flexible that parties are not afraid to engage themselves, but not so flexible that opportunistic behavior is overtly encouraged. The ease with which agents can monitor each other makes it possible to condition contractual performance on circumstances that affect them. How much information circulates may depend on local information sharing institutions -- and the ability to cross-check information -- and on agents' capacity to personally monitor each other. One of the objectives of this paper is to provide empirical evidence on how flexibility operates in practice.

\section{Section 2. Evidence from African Manufacturing}

In this section we provide evidence of relational contracting and contract flexibility among African manufacturing firms. We also seek to identify a set of robust predictors of contractual risk and of choices of dispute resolution methods. The data that we use for this purpose come from surveys of manufacturing firms conducted in six countries of Sub-Saharan Africa: Burundi, Cameroon, Côte d'Ivoire, Kenya, Zambia, and Zimbabwe. The surveys were conducted by a variety of national teams coordinated by the Regional Program of Enterprise Development (RPED) of the World Bank. Although the data are generally comparable, occasional discrepancies occur and some data are not available for certain countries.

In each of the six countries, random samples were drawn among manufacturing firms in four sectors of economic activity: textile and garment; metal products; wood and furniture; and food processing (see Table 1). Samples sizes vary from 120 firms in Burundi to 238 firms in Cameroon. Firms with fewer than 5 employees were excluded from the sample. The data thus represent the small to large scale manufacturing sector in Africa; microenterprises are ignored. In most countries, sample firms were revisited several times at one year interval. Questions on contractual disputes and on relationships with clients and suppliers, however, were only asked in the

extent that circumstances beyond your control may prevent you from repaying the bank with absolute certainty, you may very well decide that the contract is unattractive. 
first survey round. Efforts to design a questionnaire that would work in many different countries and would apply to large and small firms alike led to some compromises. In particular, the questionnaire had to be understood by all respondents, including those will little formal education, no accounting, and unsophisticated business practices. This led to the elimination of questions that required proper accounts or a thorough understanding of standard business practices such as invoicing, payment date, and finance charges. As a result, the data collected are at time a bit fuzzy as they involve judgement values by respondents, e.g., on what constitutes a 'late payment' (see infra). In spite of these shortcomings, the RPED data are probably the best available source of information on manufacturing in Sub-Saharan Africa. They also contain an unusual amount of information on relationships between firms and their clients and suppliers.

\section{Characteristics of surveyed firms}

The characteristics of sample firms are summarized in Table 1. The average number of employees for the six countries is 144; sample firms are largest in Zimbabwe (301 workers on average), and smallest in Burundi (76). The Zimbabwe sample is made of relatively old firms with an average age of 25 years; younger firms are found in the three French-speaking countries of the sample. Sixty percent of the surveyed firms have a legal status that limits the liability of the firm to its own assets; other firms are held either in sole proprietorship or in partnership. Over one quarter of the surveyed firms operate under partial or complete foreign ownership, with a high of $62 \%$ in Côte d'Ivoire and a low of $12 \%$ in Zambia. Partial or complete state ownership occurs for less than $5 \%$ of sample firms.

The ethnic makeup of the sample firms varies dramatically among countries. In two of the six countries, less than half of the sample firms have ethnic Africans as owners. Ethnic Europeans are predominant in Zimbabwe and maintain a strong presence in Cameroon and Côte d'Ivoire. Asians occupy a dominant position in Kenyan manufacturing and are present elsewhere as well (e.g., Himbara (1994)). ${ }^{4}$

The way firms deal with clients and suppliers is depicted in Table 2. Most surveyed firms sell at least part of their output to end-users of their products such as manufacturers and consumers; the rest is sold primarily to wholesalers and retailers. About a quarter of surveyed firms do at least some of their business with publicly owned entities. On average, sample firms export 9.6\% of their output; this proportion is highest in Côte d'Ivoire and lowest in Zambia. Some form of written agreement -- e.g., a signed invoice -- is used in less than half the sales to clients. The explanation lies in the length of the relationship that binds firms with their clients. Data on the number of years firms have dealt with their clients are not available but the data show that firms have on average dealt for close to 8 years with their problematic customers, that is, those that recently failed to pay or paid late. Problematic customers are primarily individual consumers. Roughly one tenth of late and non-payment cases occur with relatives or kin. ${ }^{5}$

More detailed information is available on firms' suppliers (see second part of Table 2). A quarter of the firms deal with at least one monopolist among their major suppliers, i.e., a firm who is the sole available source of a particular input. Monopolies appear more commonplace in Zimbabwe, a feature already noted by Gunning and Mumbengegwi (1995) and a possible heritage of the Unilateral Declaration of Independence (UDI) period during which an international embargo forced the country to be self-sufficient. A quarter of surveyed firms' inputs are imported; the rest is bought locally, possibly from importers. Firms in Burundi and Cameroon are more likely to be direct importers of inputs than firms in the other four countries.

\footnotetext{
4 Recent evidence of the role of ethnicity in African manufacturing is provided, for instance, by Fafchamps (1999a), Fisman (1999) and Raturi and Swamy (1999).

5 Respondents were asked to mention whether the problematic client was either (1) a relative or family member; (2) a member of the same tribe or ethnic group; or (3) none of the above. They seem to have interpreted the question of ethnicity in the narrower sense of kinship. For instance, even in a country such as Burundi where $82 \%$ of respondents are Africans and where Hutus constitute close to $90 \%$ of the population, only $7 \%$ of the respondents said that the problematic client was from the same ethnic group. This could not have occurred if respondents had interpreted ethnicity as meaning Hutu or Tutsi or white.
} 
Firms are extremely loyal to their suppliers. They purchase on average close to three quarters of their most important inputs from the same suppliers, whom they have known for 9.5 years on average. Only a fifth of the firms place infrequent orders; others have regular relationships with suppliers. These relationships, however, are primarily based on business acquaintance, not family or ethnicity; only $6 \%$ of the surveyed firms mention that one of their regular suppliers is a relative or personal friend; $12 \%$ have a supplier who is from the same 'ethnic group' as them.

Less than $40 \%$ of the surveyed firms receive credit from their supplier; this proportion is lowest in Zambia and highest in Zimbabwe. The average payment term over all sample firms is three weeks; it is of course higher for those who receive supplier credit. Trade credit among African manufacturing firms is discussed in detail in Cuevas et al. (1993), Fafchamps et al. (1994), Fafchamps, Pender and Robinson (1995), and Fafchamps (1997). In contrast, advance payment is rare: only $4.3 \%$ of the surveyed firms resort to it, often because the supplier insists on it.

Table 2 also reports the characteristics of problematic suppliers, that is, those who fail to deliver on time or who deliver deficient quality. ${ }^{6}$ Less than $10 \%$ of all cases of breach occur with first-time suppliers, possibly because firms do so little of their business with unfamiliar suppliers. ${ }^{7}$ On average, firms have known problematic suppliers for 8.2 years -- only marginally less than the length of time they have known their suppliers in general. Problematic suppliers are primarily other firms; less than $13 \%$ of recent cases of contract non-performance were with public firms.

\section{Incidence of breach of contract and dispute resolution methods}

Next we turn to the incidence of contractual disputes with clients (Table 3). The data show that roughly two thirds of the sample firms experienced some cases of late payment by clients during the 12 months preceding the survey; close to half of them faced cases of non payment. ${ }^{8}$ With 23.4 occurrences of late payment per year, the annual average of late payment cases is close to ten times the average number of non-payment cases, suggesting that late payment is a more common phenomenon than non payment.

In the great majority of cases of late and non payment, firms attempt to resolve the problem through direct negotiations with the client. This proportion is highest in Cameroon and Burundi, lowest in Zimbabwe. A small number of firms resort to private arbitration loosely defined; ${ }^{9}$ Some $8.7 \%$ of sampled firms ever called the police for help, or threatened to do so. In one fourth of the problematic cases, the dispute was either brought to the attention of lawyers and ended up in court, or the threat of legal action was resorted to by the parties. Sharp differences exist among countries: Zimbabwean firms were much more likely to go (or threaten to go) to court than those in Burundi -- a possible reflection on the relative reliability of their court systems and the size of surveyed firms in each country. Nearly one half the cases of late and non payment were settled by the time of the survey. Most of the respondents were satisfied with the terms of the settlement,

\footnotetext{
6 In the RPED surveys, the definition of what constitutes late delivery or deficient quality was de facto left to individual respondents. Surveyed firms were simply asked whether they experienced cases of late delivery and deficient quality over the 12 months preceding the survey and, if yes, how many times this occurred. Attempts to collect data on the number of days elapsed between promised delivery date and actual delivery failed: most respondents simply do not remember. Besides, the concept of promised delivery date is an ambiguous one in a world where firms do not truly expect contractual dates to be complied with. Respondents' response should thus be understood as referring to cases in which delivery occurred later than they expected.

7 Another possibility is that first-time suppliers make more effort if they wish to establish a relationship.

8 As in the case of late delivery, the definition of what constitutes a late payment was left to respondents. The reason for doing so is the same: most respondents do not keep track of the length of time elapsed between due date and actual payment date. Besides, given that African banks take several days to clear checks, and that many checks bounce, the actual payment date is a blurred concept. A late payment is thus a payment that is considered delinquent by the respondent, i.e., the payment occurred after the date at which the respondent expected payment to be made.

9 Strictly defined, private arbitration is a process by which parties to a contract agree to grant authority to a third party to legally resolve a dispute between them. The arbitrator has the power to adjudicate the dispute and his or her judgement is, in many developed countries, granted the full protection of the law, at par with other judgements. It unlikely that all respondents were acquainted with this legal definition; their answers probably lump together formal arbitrators and informal mediators with no adjudication power.
} 
with little difference across countries. Parties continued to trade in $43.8 \%$ of the cases -- more in Burundi, less in Zimbabwe -- suggesting that dispute resolution methods are moderately successful in solving disputes and bringing parties back together.

Contractual disputes with suppliers are less frequent and less dramatic (see second part of Table 3). A third of the surveyed firms experienced a late delivery in the year preceding the survey. Untimely delivery was complained about most often in Zimbabwe and least often in Burundi. The number of reported cases is also much higher in Zimbabwe than elsewhere, suggesting that input delivery risk is particularly problematic in Zimbabwe. ${ }^{10}$ Cases of deficient quality are reported by one third of the surveyed firms. As with clients, the most commonly used dispute resolution method is direct bargaining. Recourse to other dispute resolution methods is extremely rare: only $3.8 \%$ of the surveyed firms went to see a lawyer following disputes regarding late delivery or deficient quality. Fafchamps (1996) reports similar results for Ghana. Most disputes with suppliers are settled and firms continue to trade, even if they are not fully satisfied with the outcome.

To summarize, surveyed firms have long term relationships with their clients and suppliers to whom they are very loyal. These relationships are primarily grounded in business acquaintance; family, friendship, and ethnicity play little role in fostering them. The data indicate that contractual disputes occur frequently and that most firms are affected. Without equivalent data from other parts of the world, however, we cannot say whether contractual disputes are more frequent in Africa than elsewhere. The majority of contractual disputes are resolved amicably and trade is resumed in most cases. Direct negotiation is the preferred dispute resolution strategy. Detailed examination of the data reveals that outside parties such as arbitrators, lawyers, or the police, are called upon only in more serious cases of contractual breach such as those involving non payment. Taken together, these results are consistent with the importance of contractual flexibility in helping firms deal with risk, and with the role of long-term relationships is helping firms resolve contractual disputes through face-to-face negotiation.

\section{Section 3. Econometric analysis}

The preceding section has shown that countries differ in the frequency of reported cases of breach of contract and in the outcome of contractual disputes. These inter-country differences could, however, arise simply because firms located in separate countries have different characteristics. To investigate whether there exist firm characteristics that systematically affect dispute resolution and can account for some of the inter-country differences, we continue with a multivariate econometric analysis of the pooled data.

Given the total absence of previous work on these issues in Sub-Saharan Africa and elsewhere, we proceed with caution and we refrain from imposing too much structure on the estimation. We seek to identify possible determinants of three basic processes: (1) the incidence and frequency of contractual disputes; (2) the choice of dispute resolution method, given that a dispute has arisen; and (3) the outcome of the dispute. We examine these three issues in turn.

\section{The Incidence and Frequency of Contractual Breach}

We begin with an investigation of the determinants of the frequency of contractual breach. To this effect, we estimate logit regressions on whether or not a firm has experienced at least one case of breach with a supplier or a client over the 12 months preceding the survey. Regressions are run for each individual country as well as for the pooled sample of six countries. In the pooled regressions, location dummies are included to control for systematic differences across locations.

Theory suggests a variety of forces that may influence the incidence of non-compliance and, hence, the kind of regressors that have to be included in the right hand side of the regressions. Following our discussion of the theoretical literature in Section 1, we first expect non-

10 Fafchamps, Gunning and Oostendorp (1999) indeed show that contractual risk incites Zimbabwean manufacturers to accumulate inventories. 
compliance to reflect the environment in which firms operate: enterprises that buy and sell in countries or sectors in which breach of contract is frequent should face more problems than firms that operate in a more disciplined environment. Three sets of variables are used to control for market environment effects: location dummies; sectoral dummies; and the average frequency of contractual disputes and threat of court action faced by firms similar to the respondent. ${ }^{11}$ Location and sectoral dummies control for a variety of forces that operate at the local or sectoral level. Their expected effect is as follows.

Theory predicts that dispute resolution methods play an important deterrence role. North (1990), Platteau (1994a, 1994b), and Greif (1993), for instance, argue that it is the fear of sanction that induces agents to comply with their contractual obligations. If this understanding is correct, contractual breach should be less prevalent in countries with good legal institutions. Given that Zimbabwe has a more developed manufacturing sector and legal institutions generally responsive to business needs (e.g., Fafchamps, Pender and Robinson (1995)), we would therefore expect Zimbabwean manufacturers to encounter fewer cases of breach. Since Zimbabwe is the omitted country and coefficients of country dummies are thus to be interpreted as differences relative to Zimbabwe, country dummies should be negative if good legal institutions indeed reduce the incidence of contractual breach.

There is, however, another possibility, namely that good legal institutions encourage firms to take more risk because they can obtain reparation from courts. In this case, we would expect contractual breach to be more prevalent in countries offering better legal protection. Either way, the presence of good institutions would raise economic efficiency by facilitating exchange, but the source of efficiency gains would be different. In the standard case, efficiency is increased because fewer cases of breach occur; in the alternative case, efficiency rises because trade takes place between parties that would otherwise not trade -- or trade differently (e.g., without credit or delayed delivery). Which efficiency gains are larger is an empirical issue.

Small town is the omitted city size. To the extent that small towns provide inferior access to legal institutions, we expect incidence of breach to be lower in large cities and city size dummies to a negative effect on the frequency of contract non-compliance. By the same token, food processing is the omitted sector and sector dummy coefficients are relative to the food sector. Given that food products are perishable and their quality variable, we expect more delivery and quality problems in the food sector. Finally, to the extent that business environment, we expect the average frequency of non-compliance to have a positive and significant effect on the incidence of breach as firms adjust their expectations.

The incidence of contractual non-compliance is also likely to vary with characteristics of the firm. Larger firms, for instance, conduct more transactions and are thus expected to encounter more problems than small firms. ${ }^{12}$ Older firms may have identified more reliable clients and suppliers and thus face fewer problems with unreliable firms. ${ }^{13}$ The trust they have in their clients and suppliers, however, may induce them to accept delayed deliveries and payment because they believe contractual obligations will eventually be satisfied. The net effect of firm age is thus ambiguous. Firms with a limited liability status may be more willing to take risk with clients and suppliers and are thus expected to face more cases of non-compliance. Regressors for firm size,

11 These averages are constructed by country and sector, i.e., a textile firm in Kenya has a different average from a metal firm in Kenya or a textile firm in Cameroon. In addition, each observation is omitted from its own average to avoid endogeneity bias. Because of high multicollinearity across average frequency measures, a single frequency measure is used in the regression analysis: the frequency of late payment in regressions involving clients, and the frequency of late deliveries in regressions involving suppliers. In all regressions, the average frequency of threat of court action refers to payment disputes with clients -- the type of contractual breach that is most likely to result in legal proceedings.

12 The number of transactions in which a firm is engaged over a set period of time is not proportional to size, however, since larger firms typically engage in larger transactions. Moreover, firms may differ in what they mean by a transaction. For a small firm selling purely on a cash basis, a transaction is a single sale or purchase; for a large firm, a transaction can be an order or an invoice, depending on the context. These differences complicate the collection of data across firms of different sizes.

13 Bade and Chifamba (1994) and Fafchamps (1997, 1999a), for instance, provide evidence to this effect. 
age, and legal status are thus included in the regression to control for these possible influences.

Given the existence of business network effects in African manufacturing, as shown by Fafchamps (1999a), Barr (1997)), and Fisman (1999), one also expects better connected firm managers to screen clients and suppliers more easily and thus to experience fewer cases of breach. Although RPED surveys did not, as a rule, ask questions on membership in business networks, Fafchamps (1999a) and Raturi and Swamy (1999) have shown that the ethnicity of the owner/manager is an important predictor of network membership (see also Fisman (1999)). The available evidence suggests that ethnic African manufacturers are, in general, less well connected and, as a result, disadvantaged in access to supplier credit (e.g., Fafchamps (1999a)). We also suspect that foreign or state owned firms are better connected to other manufacturers, either through their mother company or through the state. We therefore include a dummy for ethnic African and ethnic European management; Asian management is the omitted category. For the same reason, we include dummies for firms that have some with foreign or state ownership. If business networks mitigate non-compliance, we expect better connected firms -- typically, foreign firms, state firms, and respondents of Asian or European ascent -- to encounter fewer cases of non-compliance.

It is also possible that the attitude of firms vis a vis contracts reflects cultural values that are shaped by ethnic identification, as argued by Greif $(1993,1994)$ in the case of medieval traders. Certain groups may have higher standards of contractual compliance and thus be quicker to classify an incident as breach. In the African case, this may be relevant for foreign owned firms or managers of European ascent. If cultural expectations are important, we would expect these firms to report more cases of breach. Note that the network and culture effects operate in opposite directions in the case of European and foreign owned firms.

The nature of the relationships that firms maintain with their clients and suppliers could also affect the incidence of contractual problems. Here we are constrained by the nature of the information collected in the surveys. For clients, we include the share of exports in total sales, as well as dummies for whether the firm sells to individual end-users and whether it sells to public entities. Although payment delays in export markets are longer (e.g., Fafchamps (1997)), the institutional mechanism of the letter of credit should reduce the incidence of payment problems in exports since payment by the buyer's bank is automatic upon presentation of the transport documents. Selling to traders (the omitted category) is generally perceived to be safer than selling to individual end-users such as manufacturers and final consumers. The reason is that traders are in general more liquid and have a faster cash turn-around (e.g., Fafchamps and Minten (1999a)). Selling to public entities is expected to raise the incidence of payment problems because governments everywhere, but particularly in Africa, are notorious for paying late.

For suppliers, more information is available. We include indicators of market power (share of imported inputs plus dummies for whether the firm faces a monopolistic supplier or a public supplier for at least one of its inputs); indicators of social capital (length of relationship with suppliers, percentage of purchases from main suppliers, and dummies whether firm buys from family and friends and whether firm only makes infrequent purchases); and indicators of credit terms (dummies for whether the firm receives supplier credit and whether it gives advance payment). We expect market power to raise the incidence of contractual problems since monopolists can more easily get away with breach. In contrast, we anticipate stronger relationships with suppliers to reduce the frequency of problems. Finally, we expect that contracts involving credit open more room for breach and thus should raise the frequency of non-compliance. Because the nature of the relationships that firms maintain with clients and suppliers is potentially endogenous, results should only be interpreted as indicative of empirical regularities.

We now investigate whether the data support the above conjectures. Logit regressions on the incidence of contractual non-compliance by clients and suppliers are presented in Tables 4 and 5. Pooled sample results are presented in full; individual country regressions are summarized as the percentage of countries for which the effect of the regressor is positive, positive and significant, and negative and significant, respectively. Coefficients of the pooled regression are reported in the form of odds ratio to improve readability; an odds ratio greater (smaller) than one means the regressor raises (reduces) the probability of a contractual problem. ${ }^{14}$

14 More specifically, an odds ratio measures the effect of a one unit change in a regressor on the probability of 
Results indicate that there are significant differences across countries and sectors but also that these differences are not well captured by contract environment variables. ${ }^{15}$ Zimbabwe (the omitted country) has a higher incidence of problems with clients and suppliers. Since Zimbabwe also is the country in our sample with the most advanced manufacturing sector and the most developed legal system, these results cast doubt on the idea that a high incidence of contractual breach is synonymous with lack of market sophistication. If anything, contract non-compliance appears more likely in better developed economies where contracts are more complex and the potential for disputes larger. For instance, the likelihood of late payment is higher if an element of credit has entered the contract; similarly, late delivery is more likely if the client firm has placed an order for future delivery.

As expected the incidence of problems is higher among large firms, but the effect is not significant for all countries and all forms of contractual non-compliance. Older firms appear to face more non-payment problems, not less, but they face fewer problems with suppliers. African-managed firms face more cases of non-payment than Asian-managed firms. The difference with European-managed firms in not significant, however. These results are difficult to interpret given that cultural differences about what constitutes normal contractual behavior may have affected responses to enumerators.

Regarding the effect of relation-specific variables, we find that selling to or buying from public firms raises the probability of disputes; the effect is significant only for late payment, however. In contrast, selling in export markets reduces the incidence of payment problems. The effect is large: a firm that exports all its output is 2.5 (2.8) times less likely to experience a late (non) payment problem than a firm that exports nothing. This may be due increased reliance on institutional mechanisms such as the letter of credit rather than exemplary behavior on the part of international buyers. ${ }^{16}$ On the supplier side, late delivery is more frequent among firms that import their raw materials, a likely reflection of the vagaries of African transportation and port systems. There is much variation across individual countries, however. These issues deserve more investigation.

On the supplier side, we find that monopolistic suppliers do not, in general, take advantage of their market power: if anything, the incidence of contractual problems is lower with monopolistic suppliers. ${ }^{17}$ Surprisingly, firms that make infrequent purchases encounter fewer problems. One likely explanation is that these firms are very small and operate on a cash-and-carry basis only -- what Fafchamps and Minten (1999b) call the flea market economy. Another surprising result is that firms that buy from family and friends encounter more late delivery problems. One possible interpretation is that it is harder to put pressure on family and friends than on regular suppliers. Finally, as expected, problems are much more frequent among firms that receive or give credit to their suppliers, a result consistent with the idea that contractual breach is more likely in more complex contracts. But the effect is significant only for deficient quality in the pooled regression.

So far, we have only a single piece of information, namely, whether respondent firms reported having experience contractual non-compliance. We now examine the reported number of cases of non-compliance using a simple tobit regression. ${ }^{18}$ Results are presented in Tables 6

experiencing at least a dispute per year, computed at the average value of all regressors. For instance, an odds ratio of 2.4 for the textile sector (Table 4) means that textile manufacturers are 2.4 times more likely than food processing manufacturers (the omitted category) to experience at least one late payment problem in the survey year.

15 Unreported regression results show that, when country and sectoral dummies are omitted, environment variables are very significant. Once country and sector dummies are included, however, they are no longer significant. This may be due to multicollinearity, given the way environment variables are constructed. This issue deserves more research.

16 The survey did not collect data on recourse to the letter of credit system, but informal discussions with respondents in Ghana, Kenya, and Zimbabwe indicate that letters of credit are used in most imports and exports from outside of Africa. Because of the informal nature of much intra-African trade, respondents seldom export or import within Africa themselves and prefer to rely on intermediaries. The only possible exception is trade with South-Africa.

17 To recall, firms with monopolistic suppliers are defined as those who report that at least one of their main suppliers is the sole available source of a particular input.

18 Tobit regression is the appropriate estimator in this case because it corrects for the fact that the dependent variable is censored at zero, i.e., that a large proportion of firms report zero problems with clients or suppliers. Data on 
and 7. They confirm that the incidence of payment problems is much larger in Zimbabwe than in the other surveyed countries, and that large firms unmistakably face more contractual problems than smaller firms -- hardly a surprise since they are involved in more transactions. Older firms seem to do better with suppliers, a result in agreement with the idea that there are returns to experience in choosing and dealing with suppliers. Tobit regression results also confirm that exporters experience fewer payment problems, probably thanks to the letter of credit system. European-managed firms report more late payment and deficient quality problems, contrary to what the business network idea had led us to expect, but a possible reflection of different cultural expectations. Other characteristics are in general not significant, possibly because of endogeneity or omitted variable bias. A thorough investigation of the causality between these various factors requires instruments that are not available in these data and is left fur future research.

\section{Dispute Resolution Methods}

According to our current understanding of market institutions (e.g., North (1990), Platteau (1994a, 1994b), and Greif (1993)), the fear of sanction is what induces agents to comply with contractual obligations. These sanctions can take several forms which are discussed, for instance, by Fafchamps (1996), namely: guilt; harassment; loss of relationship and reputation; recourse to legal institutions such as courts and lawyers; and recourse to private arbitration and, more prosaically, the police. We focus here on two types of sanctions that are important in practice: legal recourse, and loss of relationship. ${ }^{19}$

Simple theoretical models of relationships such as the ones presented by Kandori (1992), Greif (1993), Ghosh and Ray (1996), Kali (1999), Kranton (1996b), and Fafchamps (1998) predict that sanctions are applied as soon as breach of contract occurs. ${ }^{20}$ Which type of sanction is chosen depends on their relative cost and effectiveness. Given the existence of fixed costs in legal proceedings, the threat of legal action is seldom credible for small size transactions. Suing a poor individual with no assets is rarely cost effective: the chance of recovering anything by legal means is slim so that it is not worth incurring lawyers and court fees. Suing may also be unattractive if the contractual dispute is complex and the evidence hard to verify, so that the outcome of the court process is uncertain. In contrast, breaking a relationship is likely to be counterproductive if the other party is sole buyer or seller. Legal sanctions may not work either; harassment may be the only viable alternative.

Whenever there exist uncertainty regarding the cause for breach of contract, immediate sanctions need not be optimal; a more gradual approach may be called for. To see why, suppose for instance that agents can be hit by two types of shocks: temporary shocks and permanent shocks. The former make it impossible for agents to comply with their contractual obligations for a single period only; the latter make the agent permanently unable to comply (e.g., bankruptcy). Intuitively, applying harsh sanctions is appropriate only when the other party has been hit by a permanent shock. If the shock is only temporary, both parties are better off renegotiating the contract and preserving their relationship. In these circumstances, the natural response to a breach of contract is for both parties to negotiate until it becomes clear that the shock is permanent, at which point hard sanctions are applied.

The negotiation subgame is itself fraught with problems, however. Waiting for too long before suing may enable the breaching party to hide assets and evade legal sanctions. The negotiation process is thus likely to be limited in time. Renegotiation also introduces an insurancelike element into the contract. By analogy with the benefits agents can obtain by filing false insurance claims, parties may profit by calling for undue renegotiation, thereby abusing the other

the number of breaches were not collected in Cameroon; this country thus has to be dropped from the analysis.

19 Evidence of reputational sanctions in developed economies is presented, for instance, by Fukuyama (1995), Lorenz (1988), and Bernstein (1992, 1996). Hart (1988), Banerjee and Duflo (1999), Haggard, McMillan and Woodruff (1996), McMillan and Naughton (1996), Banerjee and Munshi (1999), Fafchamps and Minten (1999b), and Fafchamps (1996, 1997, 1999a) present evidence for Africa and Asia. Historical evidence is provided, for instance, by Ensminger (1992) and Greif (1993, 1994).

20 This is but an application of the optimal penal code principle of Abreu (1988): gradual sanctions are unnecessary; optimal deterrence is obtained when harsh sanctions are used to punish all deviations from cooperation. 
party's willingness to renegotiate contract terms. As a result, agents unable to monitor the situation of the other party may optimally refuse to renegotiate for fear of abuse and may opt for hard sanctions instead.

Although, as argued by Benson (1990), market exchange would become impossible in the total absence of sanctions for breach of contract, punishment of all breach of contract is not required; it is sufficient that breach of contract be punished with a sufficiently high probability. Consequently, some agents may be able to free-ride the system, i.e., refrain from incurring any of the costs associated with dispute resolution and yet expect a low probability of breach. By the same token, agents may choose to randomize, i.e., to punish only a certain percentage of breach they incur. In these cases and when it is clear that pursuing the breaching party is futile, doing nothing may well be the optimal strategy.

This brief, heuristic discussion leads us to expect firms to differ in the way they seek to resolve breach of contract. First, we expect to observe across countries and sectors some differences in reliance on legal institutions that reflect the cost and predictability of legal recourse. We control for such effects via location and sectoral dummies and the average incidence of contractual disputes. Second, large firms are more likely to engage in large transactions and thus more likely to find legal action cost effective. Third, older firms may have acquired better negotiation and monitoring skills, and are likely to be more familiar with legal institutions. We therefore expect them to be less likely to do nothing when faced with contractual problems. To the extent that limited liability status creates a moral hazard problem and weakens incentives, we expect such firms to be more casual about contractual breach and hence to be more likely to do nothing. Firms may also use their business contacts to monitor contract renegotiation; as a result we expect ethnic Africans to be more likely to either do nothing or use legal recourses given that they have fewer business connections in several of the countries we study, such as Ghana, Kenya, and Zimbabwe. ${ }^{21}$ We also include dummy variables indicating whether the firm has some foreign or state ownership. Next, firms that value relationships ought to put more emphasis on direct bargaining once problems occur. In contrast, firms that face monopolistic sellers may find it difficult to seek legal reparation. Finally, firms receiving or granting credit to their suppliers ought not to remain inactive when faced with contractual problems. We control for all these factors with the variables listed in the previous subsection. Again, some of these variables are potentially subject to endogeneity bias, a bias we cannot correct for because we do not have good instruments for relationships and network capital. Results should thus be interpreted as suggestive only.

We first examine the probability with which firms seek to negotiate and threaten court action conditional on having encountered a contractual breach. For clients we divide respondents' actions into four categories: (1) do nothing; (2) only negotiate; (3) only use legal institutions; and (4) use both bargaining and legal institutions. ${ }^{22}$ For suppliers, the third and fourth categories are merged given the small number of observations in each of them. ${ }^{23}$ Since the frequency of late delivery and deficient quality is much lower than that of recovery problems, there are much fewer observations on the supplier side.

Since firms' actions are divided into more than two categories -- four for disputes with clients, three for disputes with suppliers -- logit is no longer adequate and a multinomial regression approach is required. In the interest of simplicity, we opt for multinomial logit estimation. ${ }^{24}$ By construction, the analysis is confined to the firms that experienced contractual breach. Given the small sample size, we limit ourselves to pooled sample regressions. Results are presented in

21 See Barr (1997), Fafchamps (1999a), and Fisman (1999) for evidence.

22 In practice, the former typically precedes the latter, but we have no data on the sequence of firms' actions.

23 There are only three cases of exclusive recourse (or threat of recourse) to legal institutions for disputes with suppliers.

24 Multinomial logit has been criticized for imposing certain restrictions on agents' choices -- the so-called independence of irrelevant alternative assumption. Given the exploratory nature of our analysis, the substantial extra cost of estimating a more general multinomial model is not justified. Besides, qualitatively similar results are obtained using logit regressions on each action separately. 
Tables 8 and 9 for clients and suppliers, respectively. In both Tables, bargaining with the delinquent client or supplier is the omitted choice category, Estimated coefficients must therefore be interpreted as differences relative to 'bargaining only'. ${ }^{25}$

By far the strongest result emanating from Table 8 is that manufacturers in Zimbabwe are much more likely that those in other countries to deal with bad payers through legal action. In addition, we find that large firms are more likely to threaten court action against delinquent clients or suppliers. The effect is large and significant in both Tables. We strongly suspect that legal institutions are better in Zimbabwe than in the other five surveyed countries (e.g., Fafchamps, Pender and Robinson (1995)). In addition, large firms probably have easier access to courts given that the costs of legal proceedings are easier to amortize on larger transactions. Results from Tables 8 and 9 therefore suggest that firms with better access to courts make more use of them.

This conclusion only takes all its meaning if it is combined with the finding that large manufacturers and firms located in Zimbabwe face more cases of contract breach. Indeed these two findings combined imply that better access to legal institutions raises both usage of legal institutions and the frequency of breach. This flies in the face of the commonly held view that strong legal institutions serve to deter contractual opportunism (e.g., Platteau (1994), North (1973), Greif (1994)). Our preferred interpretation is that firms operating under the protection of an effective legal system take more risk with clients and suppliers and thus face more problems that they handle through legal channels. The outcome is the same -- legal institutions favor exchange -- but the channel through which this occurs is not that usually surmised: exchange expands not so much because breach is deterred directly but because firms become more daring in their choice of clients and suppliers.

Among smaller firms, direct negotiation in delinquent payment cases seems to be the method of choice, especially for African owners. This may reflect a cultural preference for nonconfrontational methods of dispute resolution. The length of the relationship between parties is seen to reduce the likelihood of going to court, but the effect is significant only in delivery cases. This result is consistent with the idea that valuable relationships serve to discipline contractual behavior without recourse to external enforcement mechanisms, as shown theoretically by Ghosh and Ray (1996) and Fafchamps (1998). The severity of the conflict also influences the dispute resolution method: disputes about late delivery and non-payment are less likely to be dealt with via bargaining, and more likely to trigger threats of court action, but the effect is not statistically significant for suppliers.

On the supplier side, we see that dealing with monopolistic suppliers reduces the probability of doing nothing in response to a contractual dispute. Contrary to expectations, loyalty to suppliers as measured by the percentage of purchases made from main suppliers increases the likelihood of taking no action: loyalty implies trust and hence should facilitate negotiations. Discussions with respondents nevertheless suggest that when parties are extremely well acquainted with each other, minor contractual problems such as late deliveries and quality problems are handled so easily and expeditiously that respondents do not perceive negotiation as taking place at all, i.e., 'problems take care of themselves'. Whenever the problematic supplier is a public firm, direct bargaining is less frequent, possibly because it is unlikely to be successful: public agencies are notorious for being unreliable suppliers so that negotiating with them for late deliveries and poor quality is probably seen as a waste of time.

\footnotetext{
25 For instance, a significant negative coefficient for Kenya in the 'legal institutions only' column of Table 8 means that Kenyan manufacturers are much less likely than Zimbabwean to respond to late payment with threats of court action. Since the coefficient of the Kenya dummy is small and non-significant in the other two columns, it means that Kenyan manufacturers are more likely than Zimbabwean manufacturers to deal with delinquent clients through negotiations only -- the omitted category. The reason is that, since probabilities sum to one (manufacturers must take one of the four possible actions), a reduction in the probability of undertaking one action -- legal recourse -- must translate into a increase in the probability of taking another -- here the omitted category, bargaining.
} 
We conclude with an analysis of the outcome of contractual disputes. What happens after a dispute has arisen indeed shapes firms' expectations regarding the outcome of disputes: if all disputes end with sour grapes and broken relationships, it would be optimal for firms to minimize the incidence of disputes. If, in contrast, problems with clients and suppliers are successfully resolved through bargaining or any other means, firms might be more inclined to take chances and less likely to insist on rigorous performance of contracts.

To thow light on these issues, survey respondents were asked to comment on 'the most recent case' of contractual breach they had encountered. Responses are therefore subject to truncation since some of the most recent contractual disputes have not been settled yet. We do not, however, have information on when the dispute began, so that we cannot correct for differences in the duration of disputes. The data nevertheless enable us to examine two issues: first, whether the contractual dispute was settled at the time of the interview and, in this case, whether the respondent was satisfied with the outcome; ${ }^{26}$ and second, whether the trade relationship continued after the dispute. Regressors are the same as in previous regressions, except that we also control for the method of dispute resolution used by respondents. ${ }^{27}$ Results must be interpreted with caution because both the outcome of the dispute and the choice of dispute resolution method are likely to be correlated with the severity of the dispute, which is unobserved. For instance, respondents are unlikely to call upon the police for help unless they feel that it is their only hope of getting satisfaction. The coefficients of dispute resolution methods are thus subject to omitted variable bias and should be interpreted in this light.

With these words of warning, results are presented in Tables 10 and 11 for clients and suppliers respectively. They indicate that direct bargaining is strongly associated with the settlement of disputes and the resumption of trade. In contrast, recourse to legal institutions such as lawyers, courts, and police result in a much higher probability of severed business relationship. The use of lawyers and threats of court action is also associated with less satisfactory resolution of those disputes that are settled. This is consistent with the idea that firms seek the protection of legal institutions only when they lose confidence in the other party. Conversations with respondents indeed suggest that lawyers and legal threats are not set in motion as long as firms believe the other party is acting in good faith, i.e., is trying to comply but is prevented from doing so due to circumstances beyond its control.

Among other results of interest, we note that African managed firms are more likely to settle payment disputes and to do so satisfactorily after controling for firm size, age, country, and sector of activity. Combined with evidence that shared ethnicity has a positive effect on the settlement of disputes (the positive and significant coefficient of the 'relative or same ethnicity' dummy variable), this can be interpreted as limited evidence of a more lenient attitudes toward payment disputes and a deeper emphasis on flexibility and negotiation among African entrepreneurs. Finally, we note that disputes with individual consumers are less likely to be settled, possibly because individual consumers are plenty and are more easily dispensable than firms. In contrast, results also show that, of all possible disputes, those with public entities are the worst: less likely to be settled and less likely to resume trade. One possible explanation for these results is that trade relationships are more likely to be resumed when respondents view the breaching party as an individual person than when they view it as an anonymous firm or public entity. This issue deserves more research.

\section{Conclusion}

We have presented evidence that African manufacturers operate in an environment characterized by contractual non-performance risk. Large firms face more cases of non-compliance across the board, possibly because they conduct more transactions. Of the six countries studies,

\footnotetext{
26 The small number of disputes with suppliers prevented the estimation of the satisfactory settlement regression in the supplier case.

27 Small sample size prevented the inclusion of dispute resolution methods in the trade continuation regression for supplier disputes.
} 
incidence of contractual breach is much larger in Zimbabwe in spite of the fact that this country is also the one with the most developed manufacturing sector as well as a good legal and court system. This finding contradicts the common view that contractual breach results from imperfect legal institutions: manufacturing firms in Zimbabwe are both more likely to encounter problems and to call upon the legal system when these problems occur. An alternative interpretation is that Zimbabwean firms can afford to take more chances, knowing that they can always seek the protection of the law should a problem arise. If this interpretation is correct, it implies that, unless firms feel sufficiently protected, they choose to avoid situations in which problems may arise. As a result, the incidence of problems is lower when legal institutions are less developed and the manufacturing sector unsophisticated. This may also explain why large firms, which are more likely to call upon the legal system, are also those who face more problems. Fafchamps and Minten (1999b) reach similar conclusions regarding agricultural traders in Madagascar. The role of institutions is further brought to light by the fact that exporting firms face fewer payment problems, in spite of having to collect payment from firms located in other countries. We interpreted this result as a consequence of the letter of credit mechanism whereby banks located abroad collect payment in the name of the exporting firm. In contrast, importing firms face more late deliveries, probably because of transport and customs delays.

Although more work is required to confirm our results, they are in line with the idea that most surveyed firms expect contracts to be flexible. Our findings indicate that contract nonperformance is handled primarily through direct negotiation. Only if negotiation is unsuccessful do firms turn to outsiders such as lawyers and courts and, in certain cases, the police. When this happens, the parties are extremely unlikely to resume their relationship. The existence of long term relationships with clients and suppliers appears to serve as a facilitator in these disputes, raising the probability that the dispute is settled and that the outcome is judged satisfactory. Relations based on family, friendship, or ethnicity/kinship make it easier for firms to solve disputes but also raises the incidence of contract non-performance, the two issues being possibly linked.

The paper contributes to the literature in two ways. First, it demonstrates that regarding contracts as rigid is not only inaccurate, it also fails to recognize that contractual flexibility is necessary for market exchange to take place. This finding is essential for a proper understanding of how markets operate in practice. Second, although the data did not allow us to ascertain the direction of causality between participation in international markets and contractual practices, the evidence presented nevertheless suggest that the relation between the two is strong and deserves further study. What this paper was able to show is that African manufacturers operate in an environment where contractual disputes are frequent but are mostly dealt with through direct negotiation. The great majority of disputes regarding late deliveries are resolved to the satisfaction of the parties and trade is resumed thereafter. The same is true for many disputes regarding late payment. More work is needed to assess whether African firms exposed to outside influences through trade adopt Western-style contractual practices in their local operations or rather take advantage of local tolerance for late payment and delivery to meet their stricter obligations towards international suppliers and clients.

Taken together with evidence that entrepreneurs who are ethnic Africans seek the resolution of disputes primarily through non-confrontational means, these results suggests that there may be reasons other than rent seeking and erroneous policies for why Africa trades so little with the rest of the world, namely that foreign firms find it difficult to deal with African firms and find them generally unreliable. In particular, attempts by African entrepreneurs to renegotiate delivery and payment terms ex post -- a relatively common practice in local transactions according to the data presented here -- are likely to be misinterpreted as opportunistic. While it would be ill advised to overplay the idea -- other obstacles to trade remain formidable -- it nevertheless opens the door to another way of conceiving and, hence, promoting relations between African and foreign firms, i.e., trust and network building. This issue deserves further investigation. 


\section{References}

Abreu, D., "On the Theory of Infinitely Repeated Games with Discounting," Econometrica, 56: 383-396, 1988.

Amselle, J., Les Négociants de la Savanne, Editions Anthropos, Paris, 1977.

Bade, J. and Chifamba, R., "Transaction Costs and Institutional Environment," The Manufacturing Sector in Zimbabwe: Dynamics and Constraints, Free University of Amsterdam/University of Zimbabwe, RPED Country Study Series, The World Bank, Amsterdam, April 1994.

Banerjee, A. and Munshi, K., Market Imperfections, Communities, and the Organization of Production: An Empirical Analysis of Tirupur's Garment-Export Network, Department of Economics, MIT, Cambridge, Mass., April 1999. (mimeograph).

Banerjee, A. V. and Duflo, E., Reputation Effects and the Limits of Contracting: A Study of the Indian Software Industry, Department of Economics, MIT, Cambridge, Mass., April 1999. (mimeograph).

Barr, A. M., Social Capital and Technical Information Flows in the Ghanaian Manufacturing Sector, Center for the Study of African Economies, Oxford University, Oxford, May 1997. (mimeograph).

Benson, B. L., The Enterprise of Law, Pacific Research Institute for Public Policy, San Francisco, 1990.

Bernstein, L., "Opting Out of the Legal System: Extralegal Contractual Relations in the Diamond Industry,', Journal of Legal Studies, XXI: 115-157, January 1992.

Bernstein, L., " Merchant Law in a Merchant Court: Rethinking the Code's Search for Immanent Business Norms,' University of Pennsylvania Law Review, 144(5): 1765-1821, May 1996.

Biggs, T., Moody, G., Leewen, J. v., and White, E., Africa Can Compete! Export Opportunities and Challenges in Garments and Home Products in the U.S. Market, The World Bank, Washington, D.C., March 1994. RPED Discussion Paper.

Cohen, A., Custom and Politics in Urban Africa: a Study of Hausa Migrants in Yoruba Towns, University of California Press, Berkeley, 1969.

Cuevas, C., Hanson, R., Fafchamps, M., Moll, P., and Srivastava, P., Case Studies of Enterprise Finance in Ghana, RPED, The World Bank, Washington D.C., March 1993. (draft).

Ensminger, J., Making a Market: The Institutional Transformation of an African Society, Cambridge University Press, New York, 1992.

Fafchamps, M., Biggs, T., Conning, J., and Srivastava, P., Enterprise Finance in Kenya, Regional Program on Enterprise Development, Africa Region, The World Bank, Washington, D.C., June 1994.

Fafchamps, M., Pender, J., and Robinson, E., Enterprise Finance in Zimbabwe, Regional Program for Enterprise Development, Africa Division, The World Bank, Washington, D.C., April 1995.

Fafchamps, M., "The Enforcement of Commercial Contracts in Ghana," World Development, 24(3): 427-448, March 1996.

Fafchamps, M., "Trade Credit in Zimbabwean Manufacturing," World Development, 25(3): 795-815, 1997.

Fafchamps, M., Market Emergence, Trust and Reputation, Stanford University, Stanford, February 1998. (mimeograph). 
Fafchamps, M., "Ethnicity and Credit in African Manufacturing," Journal of Development Economics, 1999a. (forthcoming).

Fafchamps, M., "Networks, Communities, and Markets in Sub-Saharan Africa: Implications for Firm Growth and Investment," Journal of African Economies, 1999b. (forthcoming).

Fafchamps, M., "The Role of Business Networks in Market Development in Sub-Saharan Africa," Community and Market in Economic Development, Masahiko Aoki and Yujiro Hayami, Stanford, March 1999c. (forthcoming).

Fafchamps, M. and Minten, B., "Relationships and Traders in Madagascar," Journal of Development Studies, August 1999a. (forthcoming).

Fafchamps, M. and Minten, B., Property Rights in a Flea Market Economy, Department of Economics, Stanford University, Stanford, February 1999b. (mimeograph).

Fafchamps, M. and Lund, S., Risk Sharing Networks in Rural Philippines, Department of Economics, Stanford University, Stanford, May 1999. (mimeograph).

Fisman, R., Decomposing the Ethnic Effect: Networks vs. Human Capital in Credit Access, DECRG, The World Bank, Washington, D.C., 1999. (mimeograph).

Fisman, R. and Raturi, M., Does Competition Encourage Cooperation? Evidence on the Effect of Competition on Trade Credit Provision, Columbia Business School and the World Bank, Washington, D.C., 1999. (mimeograph).

Fukuyama, F., Trust: The Social Virtues and the Creation of Prosperity, The Free Press Paperbacks, New York, 1995.

Geertz, C., Geertz, H., and Rosen, L., Meaning and Order in Moroccan Society, Cambridge U. P., Cambridge, 1979.

Ghosh, P. and Ray, D., "Cooperation in Community Interaction Without Information Flows," Review of Economic Studies, 63: 491-519, 1996.

Greif, A., "Contract Enforceability and Economic Institutions in Early Trade: The Maghribi Traders' Coalition,'” Amer. Econ. Rev., 83(3): 525-548, June 1993.

Greif, A., "Cultural Beliefs and the Organization of Society: A Historical and Theoretical Reflection on Collectivist and Individualist Societies," J. Polit. Econ., 102(5): 912-950, 1994.

Gunning, J. W. and Mumbengegwi, C., The Manufacturing Sector in Zimbabwe: Industrial Change under Structural Adjustment, Free University of Amsterdam and University of Zimbabwe, Amsterdam, January 1995.

Haggard, S., McMillan, J., and Woodruff, C., Trust and Search in Vietnam's Emerging Private Sector, Center for Economic Policy Research, University of California at San Diego, San Diego, November 1996. Discussion Paper 1506, 33.

Hart, K., "Kinship, Contract, and Trust: the Economic Organization of Migrants in an African City Slum,' Trust: Making and Breaking Cooperative Relations, D. Gambetta (ed.), Basil Blackwell, New York, 1988.

Hart, O. and Holmstrom, B., "The Theory of Contracts,"' Advances in Economic Theory, Truman F. Bewley (ed.), Cambridge University Press, Cambridge, 1987.

Himbara, D., "The Failed Africanization of Commerce and Industry in Kenya," World Development, 22(3): 469-482, 1994.

Kali, R., "Endogenous Business Networks," Journal of Law and Economic Organization, October 1999. (forthcoming). 
Kandori, M., "Social Norms and Community Enforcement," Review Econ. Stud., 59: 63-80, 1992.

Kranton, R. E., “The Formation of Cooperative Relationships,' Journal of Law, Economics, and Organizations, 12(1): 214-233, 1996a.

Kranton, R. E., “Reciprocal Exchange: A Self-Sustaining System," Amer. Econ. Rev., 86(4): 830-851, September 1996b.

Lorenz, E. H., "Neither Friends nor Strangers: Informal Networks of Subcontracting in French Industry," Trust: Making and Breaking Cooperative Relations, D. Gambetta (ed.), Basil Blackwell, New York, 1988.

McMillan, J. and Naughton, B., Reforming Asian Socialism: The Growth of Market Institutions, University of Michigan Press, Ann Arbor, 1996.

Meillassoux, C., The Development of Indigenous Trade and Markets in West Africa, Oxford University Press, Oxford, 1971.

Milgrom, P. R., North, D. C., and Weingast, B., "'The Role of Institutions in the Revival of Trade: The Law Merchant, Private Judges, and the Champagne Fairs,' Economics and Politics, 2(19): 1-23, 1991.

North, D. C., The Rise of the Western World, Cambridge U.P., Cambridge, 1973.

North, D. C., Institutions, Institutional Change, and Economic Performance, Cambridge University Press, Cambridge, 1990.

Platteau, J. and Abraham, A., “An Inquiry into Quasi-Credit Contracts: The Role of Reciprocal Credit and Interlinked Deals in Small-scale Fishing Communities,' J. Dev. Stud., 23 (4): 461-490, July 1987.

Platteau, J., "Behind the Market Stage Where Real Societies Exist: Part I - The Role of Public and Private Order Institutions,'” J. Development Studies, 30(3): 533-577, April 1994a.

Platteau, J., "Behind the Market Stage Where Real Societies Exist: Part II - The Role of Moral Norms,'” J. Development Studies, 30(4): 753-815, July 1994b.

Raturi, M. and Swamy, A. V., "Explaining Ethnic Differentials in Credit Market Outcomes in Zimbabwe," Economic Development and Cultural Change, 47(3): 585-604, April 1999.

Shapiro, C. and Stiglitz, J. E., "Equilibrium Unemployment as a Worker Discipline Device," Amer. Econ. Rev., 74(3): 433-444, June 1984.

Udry, C., ' 'Rural Credit in Northern Nigeria: Credit as Insurance in a Rural Economy,' World Bank Econ. Rev., 4(3): 251-269, September 1990.

Udry, C., ' Risk and Insurance in a Rural Credit Market: An Empirical Investigation in Northern Nigeria,'’ Rev. Econ. Stud., 61(3): 495-526, July 1994. 


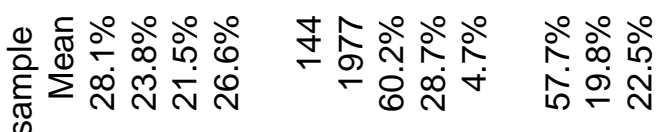
焉

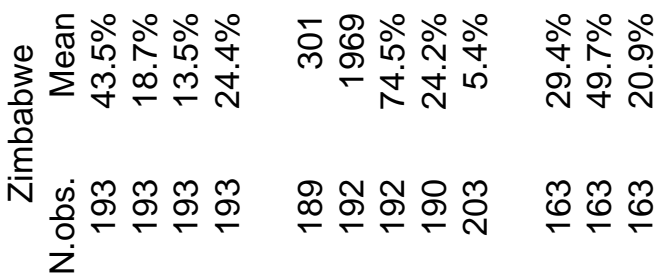

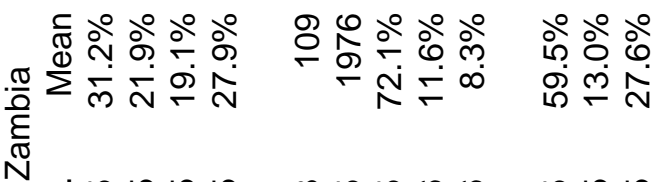

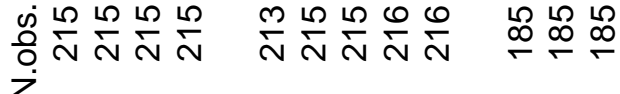

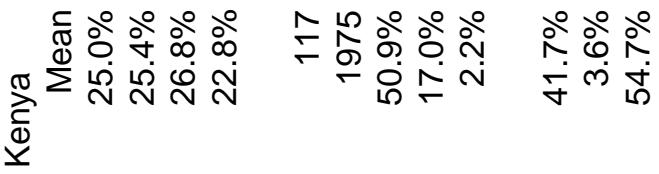

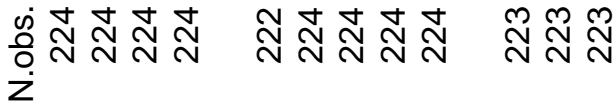

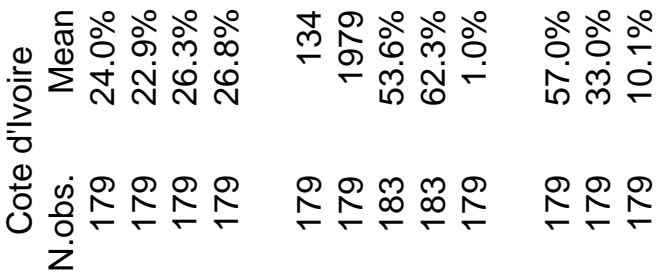

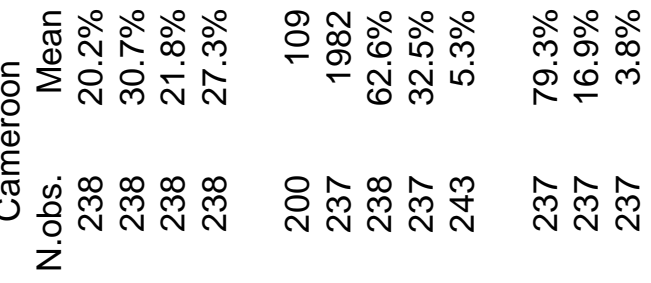

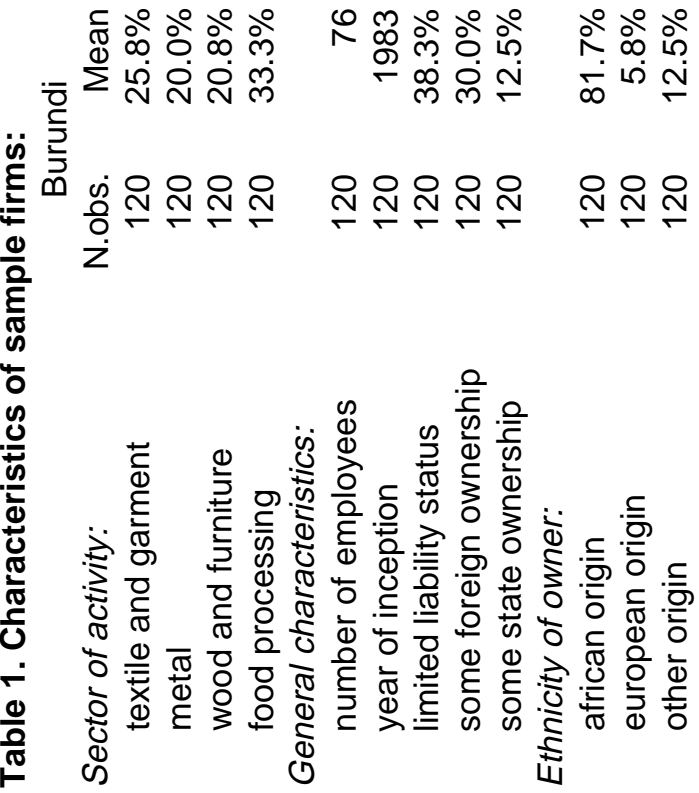




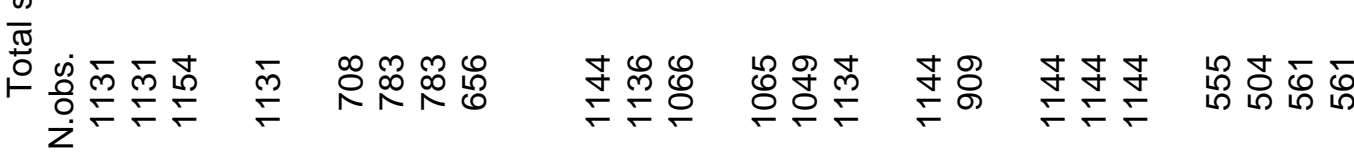

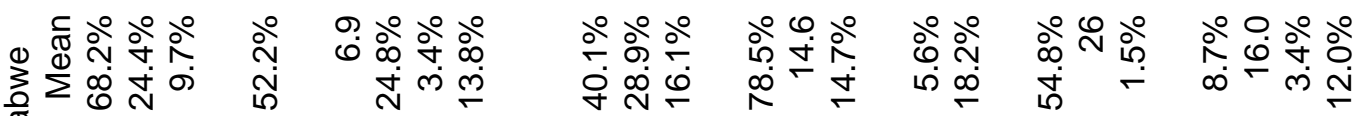
$\stackrel{\widetilde{\pi}}{\mathrm{E}}$

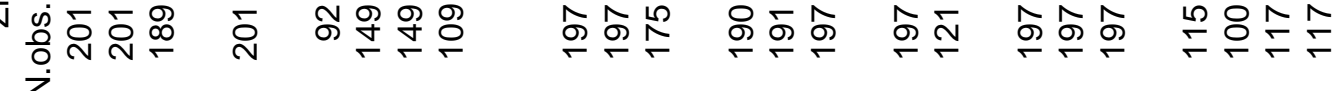

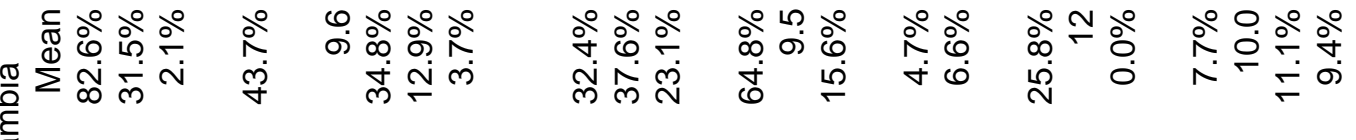

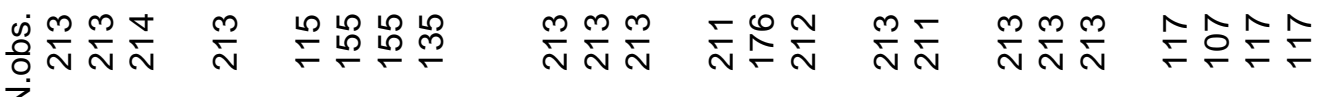

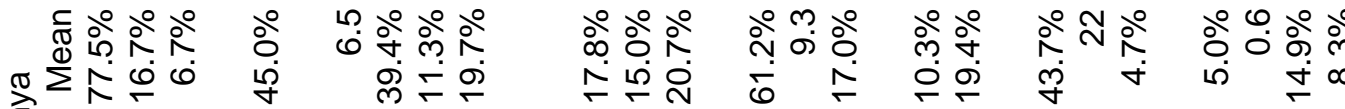
$\stackrel{1}{\Phi}$

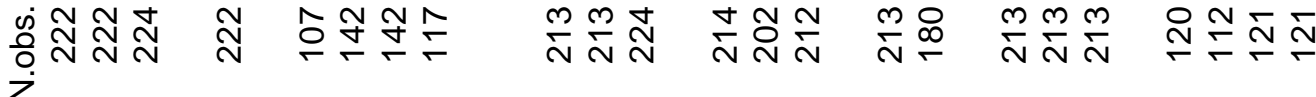

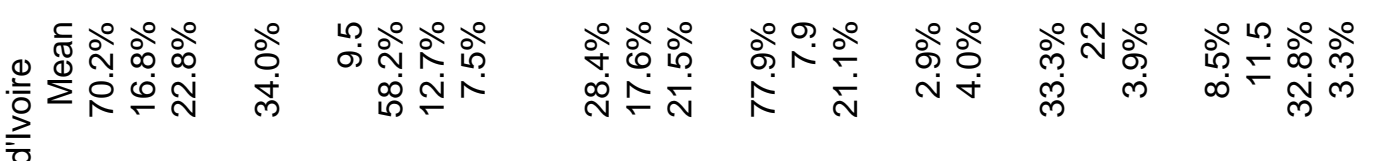

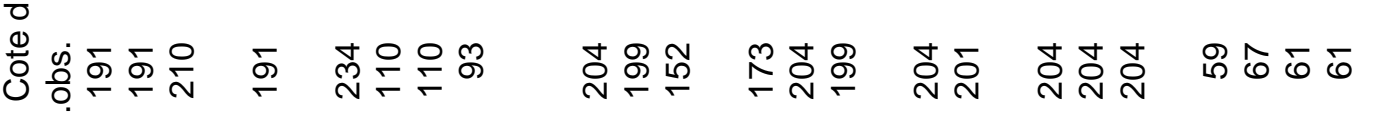

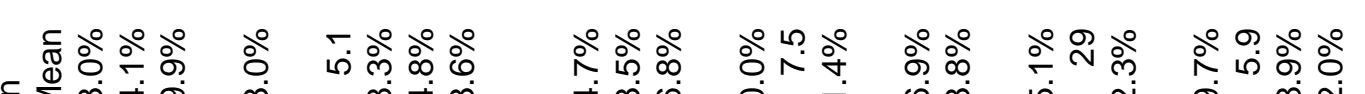
ठ림

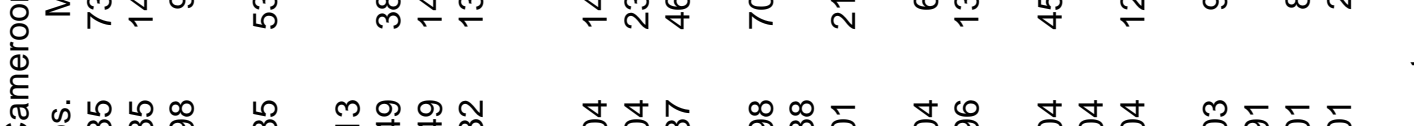
Uึ

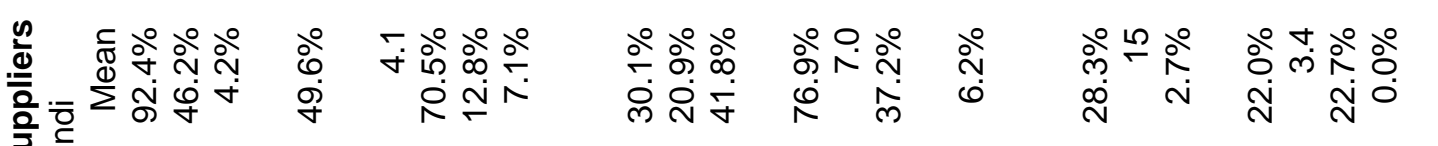
की

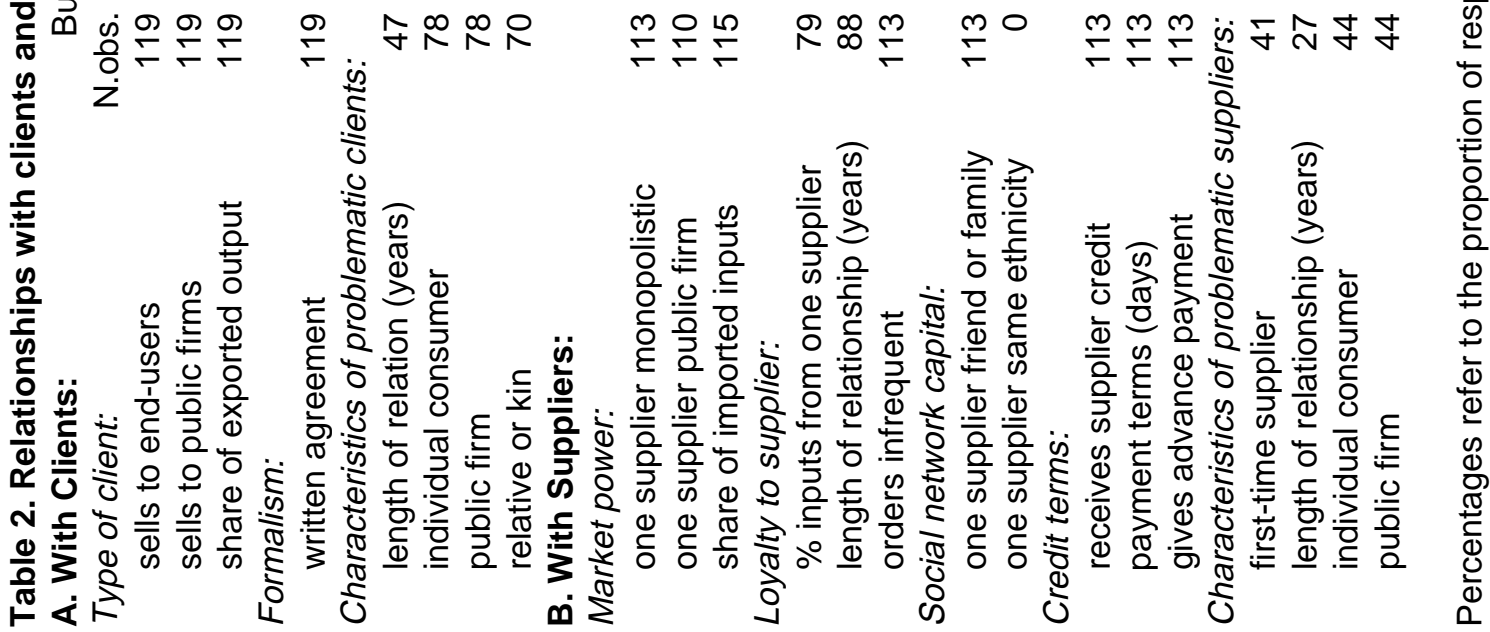




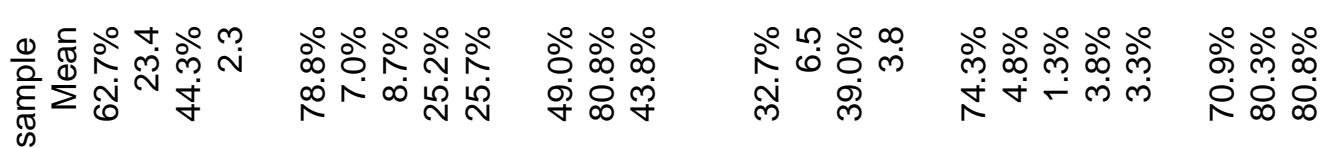

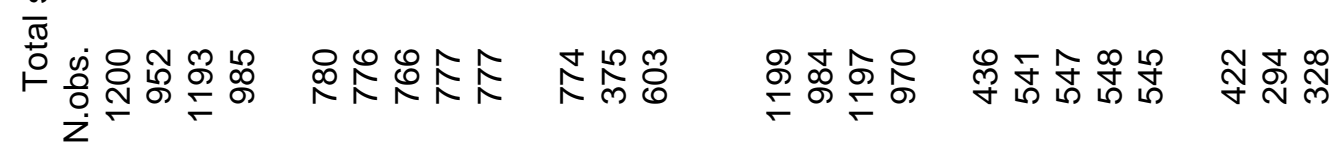

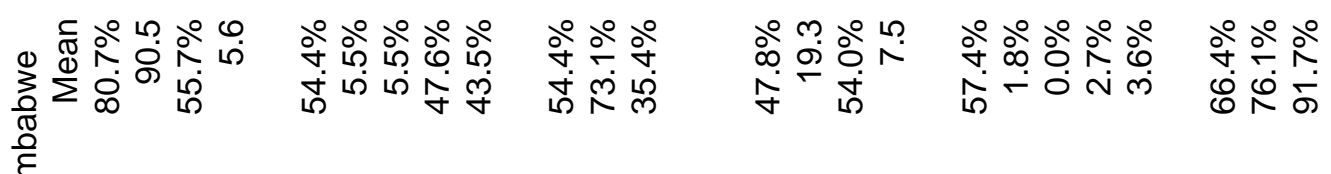

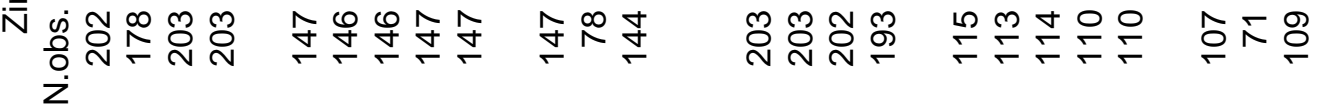

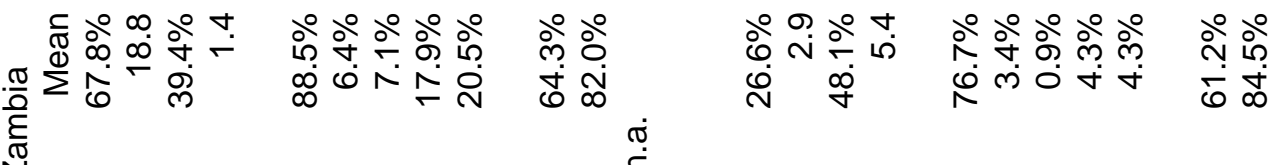

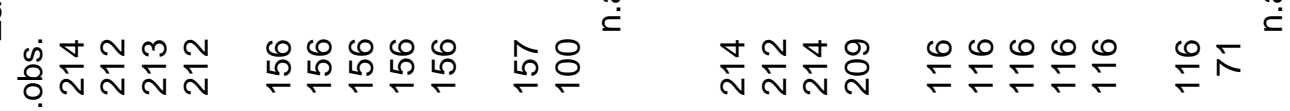

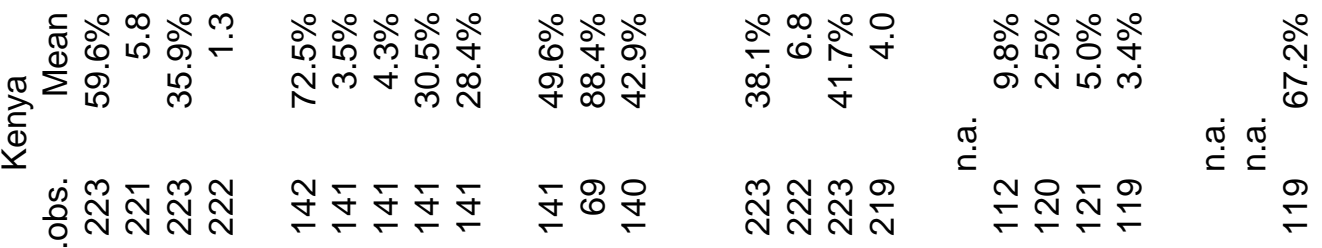

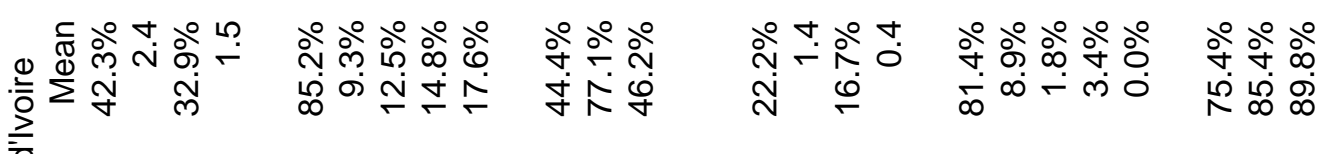

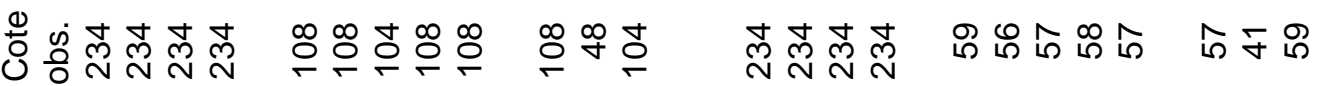
zं

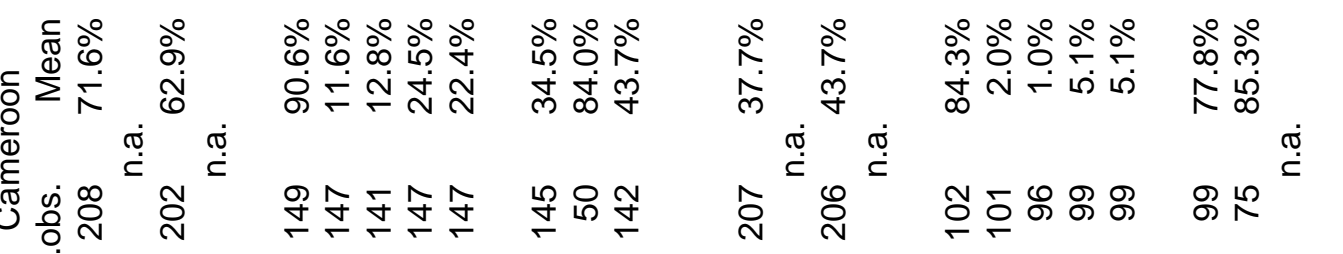
Z

ॠ ळㄷำ

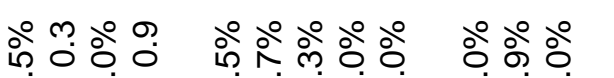

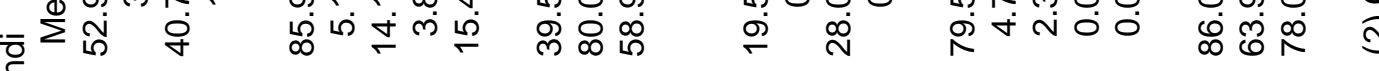
总 
Table 4. Logit Regression on the Incidence of Contractual Non-Compliance By Clients

(Robust standard errors reported using country-level clustering)

\begin{tabular}{|c|c|c|c|c|c|c|c|c|c|c|}
\hline \multirow[b]{2}{*}{ Location dummies (1) } & \multicolumn{2}{|c|}{$\begin{array}{c}\text { Late payment } \\
\text { Pooled regression }\end{array}$} & \multicolumn{3}{|c|}{$\begin{array}{l}\text { Country regressions: } \\
\% \text { reg. where coefficient is: } \\
\text { positive posit. \& negat. \& }\end{array}$} & \multicolumn{2}{|c|}{$\begin{array}{c}\text { Non-payment } \\
\text { Pooled regression }\end{array}$} & \multicolumn{3}{|c|}{$\begin{array}{l}\text { Country regressions: } \\
\% \text { reg. where coefficient is: }\end{array}$} \\
\hline & Odds ratio & z stat. & $\begin{array}{l}\text { positive } \\
\text { (4) }\end{array}$ & $\begin{array}{l}\text { posit. \& } \\
\text { signif. }\end{array}$ & $\begin{array}{l}\text { negat. \& } \\
\text { signif. }\end{array}$ & Odds ratio & z stat. & $\begin{array}{l}\text { positive } \\
\text { (4) }\end{array}$ & $\begin{array}{l}\text { posit. \& } \\
\text { signif. }\end{array}$ & $\begin{array}{l}\text { negat. \& } \\
\text { signif. }\end{array}$ \\
\hline Kenya & 0.362 & -1.543 & n.a. & n.a. & n.a. & 0.567 & -1.557 & n.a. & n.a. & n.a. \\
\hline Cameroon & 0.669 & -0.940 & n.a. & n.a. & n.a. & 2.140 & 2.541 & n.a. & n.a. & n.a. \\
\hline Cote d'Ivoire & 0.234 & -1.403 & n.a. & n.a. & n.a. & 0.782 & -0.586 & n.a. & n.a. & n.a. \\
\hline Burundi & 0.263 & -1.579 & n.a. & n.a. & n.a. & 0.759 & -0.782 & n.a. & n.a. & n.a. \\
\hline Zambia & 0.391 & -1.691 & n.a. & n.a. & n.a. & 0.578 & -1.457 & n.a. & n.a. & n.a. \\
\hline Main city & 1.088 & 0.380 & $67 \%$ & $0 \%$ & $0 \%$ & 1.369 & 0.921 & $50 \%$ & $17 \%$ & $0 \%$ \\
\hline Secondary city & 1.165 & 0.469 & $75 \%$ & $0 \%$ & $0 \%$ & 1.396 & 1.262 & $75 \%$ & $25 \%$ & $0 \%$ \\
\hline \multicolumn{11}{|l|}{ Sectoral dummies: } \\
\hline Textile & 2.397 & 3.487 & $100 \%$ & $50 \%$ & $0 \%$ & 1.912 & 1.870 & $67 \%$ & $17 \%$ & $0 \%$ \\
\hline Metal & 1.972 & 2.001 & $83 \%$ & $50 \%$ & $0 \%$ & 1.647 & 0.975 & $67 \%$ & $33 \%$ & $17 \%$ \\
\hline Wood & 2.457 & 2.334 & $67 \%$ & $67 \%$ & $0 \%$ & 1.674 & 1.538 & $50 \%$ & $17 \%$ & $0 \%$ \\
\hline \multicolumn{11}{|l|}{ Contractual environment: (5) } \\
\hline Incidence of payment problems & 0.658 & -0.201 & n.a. & n.a. & n.a. & 0.557 & -0.287 & n.a. & n.a. & n.a. \\
\hline Recourse to legal system & 0.450 & -0.700 & n.a. & n.a. & n.a. & 1.505 & 0.493 & n.a. & n.a. & n.a. \\
\hline \multicolumn{11}{|l|}{ Firm characteristics: } \\
\hline Size (2) & 1.229 & 2.048 & $50 \%$ & $33 \%$ & $0 \%$ & 1.132 & 1.075 & $67 \%$ & $33 \%$ & $0 \%$ \\
\hline Age (3) & 1.247 & 1.344 & $67 \%$ & $17 \%$ & $0 \%$ & 1.283 & 2.283 & $67 \%$ & $33 \%$ & $0 \%$ \\
\hline Limited liability status & 1.204 & 0.804 & $83 \%$ & $33 \%$ & $17 \%$ & 0.921 & -0.343 & $33 \%$ & $17 \%$ & $17 \%$ \\
\hline Some state ownership & 0.842 & -0.628 & $80 \%$ & $0 \%$ & $0 \%$ & 1.179 & 0.516 & $100 \%$ & $20 \%$ & $0 \%$ \\
\hline Some foreign ownership & 0.702 & -3.451 & $33 \%$ & $0 \%$ & $0 \%$ & 0.972 & -0.177 & $33 \%$ & $0 \%$ & $0 \%$ \\
\hline African owner/manager & 1.444 & 1.383 & $83 \%$ & $33 \%$ & $0 \%$ & 1.468 & 5.175 & $83 \%$ & $17 \%$ & $0 \%$ \\
\hline European owner/manager & 1.353 & 1.318 & $67 \%$ & $33 \%$ & $0 \%$ & 1.407 & 1.353 & $67 \%$ & $17 \%$ & $0 \%$ \\
\hline \multicolumn{11}{|l|}{ Relationship with clients: } \\
\hline Sell to manufacturers/consumers & 0.974 & -0.117 & $50 \%$ & $17 \%$ & $0 \%$ & 1.156 & 1.043 & $50 \%$ & $17 \%$ & $0 \%$ \\
\hline Sell to public firms & 1.583 & 2.597 & $83 \%$ & $17 \%$ & $0 \%$ & 1.095 & 0.778 & $50 \%$ & $0 \%$ & $0 \%$ \\
\hline Share of exports in sales & 0.395 & -6.300 & $50 \%$ & $17 \%$ & $17 \%$ & 0.355 & -2.528 & $17 \%$ & $0 \%$ & $17 \%$ \\
\hline Number of observations & 961 & & & & & 954 & & & & \\
\hline Pseudo R-squared & 0.090 & & & & & 0.061 & & & & \\
\hline Correctly classified observations & $67 \%$ & & & & & $63 \%$ & & & & \\
\hline
\end{tabular}

(1) Zimbabwe is the omitted country; small town is the omitted city category.

(2) Firm size $=\log$ (number of employees +1); (3) Firm age = log(1995 - year of inception).

(4) Certain variables, such as secondary city and some state ownership, are dropped from some country-level regressions because they do not apply. (5) In country-level regressions, contractual environment variables must be dropped because by construction they are collinear with sectoral dummies. Significance in country regressions is taken at the $10 \%$ level. 
Table 5. Logit Regression on the Incidence of Contractual Non-Compliance By Suppliers

(Robust standard errors reported using country-level clustering)

\begin{tabular}{|c|c|c|c|c|c|c|c|c|c|c|}
\hline \multirow[b]{2}{*}{ Location dummies (1) } & \multicolumn{2}{|c|}{$\begin{array}{l}\text { Late delivery } \\
\text { Pooled regression }\end{array}$} & \multicolumn{3}{|c|}{$\begin{array}{l}\text { Country regressions: } \\
\% \text { reg. where coefficient is: } \\
\text { positive posit. \& neqat. \& }\end{array}$} & \multicolumn{2}{|c|}{\begin{tabular}{|l} 
Deficient quality \\
Pooled regression
\end{tabular}} & \multicolumn{3}{|c|}{$\begin{array}{l}\text { Country regressions: } \\
\% \text { reg. where coefficient is: }\end{array}$} \\
\hline & Pdds ratio & z stat. & (4) & signif. & signif. & Odds ratio & z stat. & (4) & signif. & signif. \\
\hline Kenya & 0.622 & -1.837 & n.a. & n.a. & n.a. & 0.679 & -0.496 & n.a. & n.a. & n.a. \\
\hline Cameroon & 0.426 & -8.241 & n.a. & n.a. & n.a. & 0.635 & -0.750 & n.a. & n.a. & n.a. \\
\hline Cote d'Ivoire & 0.245 & -6.252 & n.a. & n.a. & n.a. & 0.220 & -0.949 & n.a. & n.a. & n.a. \\
\hline Burundi & 0.129 & -7.751 & n.a. & n.a. & n.a. & 0.327 & -0.918 & n.a. & n.a. & n.a. \\
\hline Zambia & 0.246 & -3.924 & n.a. & n.a. & n.a. & 0.911 & -0.131 & n.a. & n.a. & n.a. \\
\hline Main city & 1.441 & 1.225 & $33 \%$ & $17 \%$ & $0 \%$ & 1.107 & 0.379 & $50 \%$ & $17 \%$ & $17 \%$ \\
\hline Secondary city & 1.182 & 0.579 & $50 \%$ & $0 \%$ & $0 \%$ & 1.151 & 0.505 & $25 \%$ & $0 \%$ & $0 \%$ \\
\hline \multicolumn{11}{|l|}{ Sectoral dummies: } \\
\hline Textile & 0.621 & -1.420 & $50 \%$ & $0 \%$ & $50 \%$ & 0.655 & -1.392 & $33 \%$ & $0 \%$ & $17 \%$ \\
\hline Metal & 0.707 & -1.238 & $33 \%$ & $17 \%$ & $33 \%$ & 0.410 & -1.434 & $17 \%$ & $0 \%$ & $17 \%$ \\
\hline Wood & 0.579 & -1.431 & $40 \%$ & $0 \%$ & $20 \%$ & 0.501 & -1.546 & $0 \%$ & $0 \%$ & $33 \%$ \\
\hline \multicolumn{11}{|l|}{ Contractual environment: (5) } \\
\hline Incidence of supplier problems & 0.215 & -0.738 & n.a. & n.a. & n.a. & 0.390 & -0.265 & n.a. & n.a. & n.a. \\
\hline Recourse to legal system & 0.976 & -0.027 & n.a. & n.a. & n.a. & 0.614 & -0.377 & n.a. & n.a. & n.a. \\
\hline \multicolumn{11}{|l|}{ Firm characteristics: } \\
\hline Size (2) & 1.373 & 4.048 & $67 \%$ & $50 \%$ & $0 \%$ & 1.240 & 3.552 & $83 \%$ & $50 \%$ & $17 \%$ \\
\hline Age (3) & 0.751 & -1.802 & $17 \%$ & $0 \%$ & $17 \%$ & 0.705 & -1.929 & $17 \%$ & $0 \%$ & $33 \%$ \\
\hline Limited liability status & 1.237 & 1.053 & $67 \%$ & $17 \%$ & $0 \%$ & 1.039 & 0.266 & $67 \%$ & $17 \%$ & $0 \%$ \\
\hline Some state ownership & 0.858 & -0.438 & $33 \%$ & $33 \%$ & $0 \%$ & 1.388 & 0.499 & $50 \%$ & $50 \%$ & $0 \%$ \\
\hline Some foreign ownership & 1.029 & 0.207 & $67 \%$ & $17 \%$ & $0 \%$ & 0.655 & -1.264 & $50 \%$ & $0 \%$ & $17 \%$ \\
\hline African owner/manager & 0.779 & -0.652 & $33 \%$ & $0 \%$ & $17 \%$ & 1.155 & 0.676 & $50 \%$ & $17 \%$ & $0 \%$ \\
\hline European owner/manager & 0.963 & -0.242 & $50 \%$ & $17 \%$ & $0 \%$ & 1.345 & 0.828 & $83 \%$ & $17 \%$ & $0 \%$ \\
\hline \multicolumn{11}{|l|}{ Relationship with suppliers: } \\
\hline One supplier monopolistic & 1.194 & 0.806 & $67 \%$ & $17 \%$ & $0 \%$ & 0.907 & -0.547 & $50 \%$ & $0 \%$ & $0 \%$ \\
\hline One supplier public firm & 1.140 & 0.438 & $67 \%$ & $17 \%$ & $0 \%$ & 1.274 & 1.448 & $33 \%$ & $0 \%$ & $17 \%$ \\
\hline Share of imported inputs & 1.007 & 2.730 & $67 \%$ & $17 \%$ & $0 \%$ & 0.998 & -0.489 & $33 \%$ & $0 \%$ & $17 \%$ \\
\hline$\%$ purchases from main supplier & 1.000 & -0.005 & $33 \%$ & $0 \%$ & $33 \%$ & 0.994 & -1.248 & $0 \%$ & $0 \%$ & $17 \%$ \\
\hline Length of relationship (6) & 0.985 & -0.332 & $50 \%$ & $0 \%$ & $0 \%$ & 1.037 & 0.306 & $50 \%$ & $17 \%$ & $17 \%$ \\
\hline One supplier friend or family & 2.068 & 3.183 & $100 \%$ & $33 \%$ & $0 \%$ & 1.182 & 0.862 & $67 \%$ & $0 \%$ & $0 \%$ \\
\hline Dummy for infrequent purchases & 0.719 & -1.291 & $50 \%$ & $17 \%$ & $0 \%$ & 0.731 & -1.883 & $67 \%$ & $17 \%$ & $0 \%$ \\
\hline Receives supplier credit & 1.249 & 1.185 & $50 \%$ & $17 \%$ & $0 \%$ & 1.326 & 1.846 & $67 \%$ & $33 \%$ & $0 \%$ \\
\hline Gives advance payment & 1.169 & 0.604 & $50 \%$ & $25 \%$ & $0 \%$ & 2.921 & 3.553 & $75 \%$ & $25 \%$ & $0 \%$ \\
\hline Number of observations & 803 & & & & & 802 & & & & \\
\hline Pseudo R-squared & 0.132 & & & & & 0.084 & & & & \\
\hline Correctly classified observations & $69 \%$ & & & & & $65 \%$ & & & & \\
\hline
\end{tabular}

(1) Zimbabwe is the omitted country; small town is the omitted city category.

(2) Firm size $=\log$ (number of employees +1 ); (3) Firm age $=\log (1995-$ year of inception).

(4) Certain variables, such as secondary city and some state ownership, are dropped from some country-level regressions because they do not apply. (5) In country-level regressions, contractual environment variables must be dropped because by construction they are collinear with sectoral dummies. Significance in country regressions is taken at the $10 \%$ level.

(6) Log of average length of relationship with suppliers in years +1 . 
Table 6. Tobit Regression on the Incidence of Contractual Breach By Clients

Dependent variable is the log of the number of problems per year +1 .

Location dummies (1)

Late payment

Kenya

Coef tstat.

Coef. t stat.

Cote d'Ivoire

$-0.965$

$-2.123$

Coef.

t stat.

Burundi

$-2.113$

$-3.108$

$-1.639$

$-4.062$

Zambia

$-1.593$

$-2.689$

$-1.949$

$-4.995$

Main city

$-0.720$

$-1.647$

$-1.801$

$-5.172$

Secondary city

0.070

0.327

0.330

1.881

0.204

0.752

0.117

0.508

Sectoral dummies:

Textile

0.941

3.612

0.105

0.496

Metal

0.440

1.591

$-0.072$

$-0.338$

Wood

0.568

2.061

0.106

0.499

Contractual environment: (5)

Incidence of payment problems

$0.038 \quad 0.032$

0.980

0.929

Recourse to legal system

$-0.203$

$-0.255$

$-0.406$

$-0.616$

Firm characteristics:

Size (2)

0.319

4.343

0.109

1.886

Age (3)

0.128

0.999

0.169

1.650

Limited liability status

0.141

0.670

$-0.302$

$-1.750$

Some state ownership

$-0.121$

$-0.269$

0.475

1.444

$-0.188$

$-0.850$

0.165

0.957

African owner/manager

0.301

1.362

0.256

1.434

European owner/manager

0.458

1.758

0.014

0.068

Relationship with clients:

Sell to manufacturers/consumers

0.258

1.208

0.141

0.807

0.274

1.399

0.092

0.584

Share of exports in sales

$-0.860$

$-2.008$

$-0.751$

$-2.180$

$-0.763$

$-0.636$

0.055

0.073

Number of observations

778

735

of which are zero

333

413

0.074

0.082

(1) Zimbabwe is the omitted country; small town is the omitted city category.

(2) Firm size $=\log ($ number of employees +1$)$; (3) Firm age $=\log (1995-$ year of inception). 
Table 7. Tobit Regression on the Incidence of Contractual Breach By Suppliers

Dependent variable is the log of the number of problems per year +1 .

Location dummies (1)

Late delivery

Kenya

Coef. t stat.

Deficient quality

Cote d'Ivoire

$-0.768-1.554$

Coef.

t stat.

Burundi

$-2.906$

$-3.788$

$-0.090$

$-0.218$

Zambia

$-3.333$

$-3.678$

$-1.721$

$-2.239$

Main city

Secondary city

$-1.962$

$-2.887$

$-0.996$

$-1.423$

0.482

1.465

0.498

1.185

$-0.046$

$-0.116$

0.259

1.137

Sectoral dummies:

Textile

$-0.579$

$-1.640$

0.020

0.072

Metal

$-0.269$

$-0.745$

$-0.708$

$-2.429$

Wood

$-0.174$

$-0.458$

$-1.274$

$-3.021$

Contractual environment: (5)

Incidence of supplier problems

$-2.705$

$-1.227$

$-0.706$

$-2.079$

Recourse to legal system

0.098

0.091

$-1.135$

$-0.729$

Firm characteristics:

Size (2)

0.408

3.862

0.318

0.404

Age (3)

$-0.401$

$-1.918$

0.233

3.017

Limited liability status

0.341

1.125

$-0.406$

$-2.642$

Some state ownership

Some foreign ownership

0.379

0.576

$-0.059$

$-0.274$

$-0.089$

$-0.284$

0.917

1.869

African owner/manager

$-0.392$

$-1.287$

$-0.186$

$-0.769$

European owner/manager

0.318

0.930

$-0.031$

$-0.137$

Relationship with suppliers:

One supplier monopolistic

One supplier public firm

0.331

1.252

0.631

2.405

Share of imported inputs

$-0.058$

$-0.209$

$-0.075$

$-0.386$

0.011

2.623

0.122

0.599

0.002

0.408

$-0.004$

$-1.223$

$\%$ purchases from main supplier

$-0.002$

$-0.016$

$-0.003$

$-0.958$

1.155

2.932

0.075

0.802

One supplier friend or family

$-0.701$

$-2.233$

0.146

0.466

Dummy for infrequent purchases

0.237

0.959

$-0.126$

$-0.566$

$-0.680$

$-0.912$

0.390

2.098

Gives advance payment

0.499

0.336

0.725

1.410

Intercept

659

0.898

0.651

Number of observations of which are zero

438

660

390

0.117

0.079

(1) Zimbabwe is the omitted country; small town is the omitted city category.

(2) Firm size $=\log$ (number of employees +1 ); (3) Firm age $=\log (1995$ - year of inception).

(4) Log of average length of relationship with suppliers in years +1 . 
Table 8. Multinomial Logit Regression on Conflict Resolution Method With Clients

Direct bargaining only is the omitted category.

Location dummies (1)
Kenya
Cameroon
Cote d'Ivoire
Burundi
Zambia
Main city
Secondary city
Sectoral dummies:
Textile
Metal
Wood
Average incidence of problems:
Firm characteristics:
Size (2)
Age (3)
Limited liability status
Some state ownership
Some foreign ownership
African owner/manager
European owner/manager
Relationship with clients:
Sell to manufacturers/consumers
Sell to public firms
Share of exports in sales
Characteristics of problematic client:
Individual
Relative or same ethnicity
Length of relationship (4)
Dispute is about non-payment (5):
Intercept

\section{Doing nothing}

Coef. z stat.

$0.224 \quad 0.186$

$0.122 \quad 0.110$

0.132

$-1.174$

$-0.603$

0.094

$-0.782$

$-0.528$

$-0.079$

0.435

$-0.133$

0.626

$-0.438$

0.384

$-0.949$

$-0.512$

$-0.741$

0.599

$-1.378$

$-0.142$

$-0.079$

$-0.212$

$-0.335$

$-0.557$

0.557

$-32.618$

$-1.050$

$-1.739$

$-1.091$

0.886

0.000

$-1.501$

$-2.687$

$-1.240$

0.291

$-1.209$

0.477

$-1.491$

$-1.426$

$-1.003$

\subsection{7}

$-0.727$

0.122

2.395

$-1.006$

0.469

$-0.051$

$-0.412$

$-0.107$

$-0.157$

360

0.248
Legal institutions only (6)

Coef.

$-4.209$

$-3.214$

$-6.052$

$-37.147$

$-5.038$

$-0.059$

0.798

0.221

1.203

$-1.585$

$-12.018$

1.029

0.607

0.728

$-34.584$

$-0.268$

$-0.417$

$-1.924$

0.156

$-0.058$

$-2.563$

z stat.

$-2.749$

$-2.068$

$-2.450$

0.000

$-3.390$

$-0.061$

0.777

0.242

1.256

$-1.539$

$-2.019$

\subsection{8}

1.137

0.739

0.000

$-0.327$

$-0.472$

$-1.865$

0.229

$-0.074$

$-1.164$

1.175

1.578

$-0.584$

$-0.580$

$-1.364$

1.865

0.249

2.882

0.067
Bargaining + Legal institutions

Coef. z stat.

$-0.010 \quad-0.012$

$1.008 \quad 1.521$

$-0.535 \quad-0.565$

$\begin{array}{ll}-0.706 & -0.807\end{array}$

$\begin{array}{ll}-0.467 & -0.615\end{array}$

$0.062 \quad 0.150$

$\begin{array}{ll}-0.217 & -0.412\end{array}$

$\begin{array}{ll}-0.123 & -0.264\end{array}$

$0.549 \quad 1.096$

$-0.048 \quad-0.104$

$\begin{array}{ll}-1.100 & -0.439\end{array}$

0.362

0.550

0.636

1.107

$-0.308$

$-0.289$

$-0.221$

0.239

$-0.183$

$-0.930$

0.448

$-0.381$

$-0.291$

1.135

$-3.613$

(1) Zimbabwe is the omitted country; small town is the omitted city category.
(2) Firm size $=\log$ (number of employees +1 ); (3) Firm age $=\log (1995$ - year of inception).

(4) Length of relationship $=\log$ (years of acquaintance with problematic client +1 ).

(5) As opposed to late payment.

(6) Recourse to one or more of the following: private arbitration; police; lawyers; courts.

Threats of recourse to police and courts are included. 
Table 9. Multinomial Logit Regression on Conflict Resolution Method With Suppliers

Direct bargaining only is the omitted category.

\begin{tabular}{|c|c|c|c|c|}
\hline \multirow[b]{2}{*}{ Location dummies (1) } & \multicolumn{2}{|c|}{ Doing nothing } & \multicolumn{2}{|c|}{ Legal institutions (5) } \\
\hline & Coef. & z stat. & Coef. & z stat. \\
\hline Cameroon & -1.232 & -1.547 & 0.273 & 0.205 \\
\hline Ivory-Coast & -2.130 & -1.803 & -1.028 & -0.527 \\
\hline Burundi & -1.503 & -1.118 & -1.528 & -0.669 \\
\hline Zambia & -1.229 & -1.317 & -0.592 & -0.367 \\
\hline Main city & 0.535 & 1.048 & 0.122 & 0.143 \\
\hline Secondary city & 0.456 & 0.777 & -0.200 & -0.193 \\
\hline \multicolumn{5}{|l|}{ Sectoral dummies: } \\
\hline Textile & -0.903 & -1.569 & -1.863 & -1.770 \\
\hline Metal & -0.802 & -1.315 & -0.861 & -0.995 \\
\hline Wood & -1.542 & -1.979 & -1.722 & -1.300 \\
\hline Average incidence of problems: & -1.005 & -0.315 & -7.952 & -1.497 \\
\hline \multicolumn{5}{|l|}{ Firm characteristics: } \\
\hline Size (2) & 0.087 & 0.462 & 0.564 & 2.009 \\
\hline Age (3) & 0.530 & 1.641 & 0.499 & 0.999 \\
\hline Limited liability status & -0.795 & -1.809 & 0.030 & 0.037 \\
\hline Some state ownership & -0.281 & -0.322 & -0.905 & -0.697 \\
\hline Some foreign ownership & 0.222 & 0.418 & -0.259 & -0.303 \\
\hline African owner/manager & 0.120 & 0.237 & 0.686 & 0.798 \\
\hline European owner/manager & -0.642 & -1.226 & -0.489 & -0.478 \\
\hline \multicolumn{5}{|l|}{ Relationship with supplier: } \\
\hline One supplier monopolistic & -0.764 & -1.779 & -0.191 & -0.259 \\
\hline One supplier public firm & 0.587 & 1.490 & -0.674 & -0.909 \\
\hline Share of imported inputs & -0.013 & -1.872 & 0.003 & 0.243 \\
\hline$\%$ purchases from main supplier & 0.020 & 2.410 & 0.016 & 1.207 \\
\hline Length of relationship (3) & -0.225 & -0.977 & -0.617 & -1.824 \\
\hline One supplier friend or family & 0.808 & 1.312 & -0.185 & -0.151 \\
\hline Dummy for infrequent purchases & -0.003 & -0.005 & -0.394 & -0.509 \\
\hline Receives supplier credit & 0.166 & 0.404 & 0.643 & 0.998 \\
\hline Gives advance payment & 0.124 & 0.125 & 0.747 & 0.693 \\
\hline Dispute about deficient quality (4): & -0.577 & -1.534 & -0.021 & -0.035 \\
\hline \multicolumn{5}{|c|}{ Characteristics of problematic supplier: } \\
\hline Dummy if first time supplier & -32.299 & 0.000 & 1.805 & 1.144 \\
\hline Length of relationship (3) & -0.426 & -1.687 & 0.074 & 0.176 \\
\hline Dummy if public firm & 1.613 & 2.154 & 2.874 & 2.455 \\
\hline Dummy if individual consumer & 0.786 & 1.127 & -0.364 & -0.254 \\
\hline Intercept & 0.096 & 0.042 & -1.242 & -0.345 \\
\hline Number & $<0$ & & & \\
\hline Pseudo R-squared & 0.191 & & & \\
\hline
\end{tabular}

(1) Firm size $=\log ($ number of employees +1$)$; (2) Firm age $=\log (1995-$ year of inception).

(3) Log of average length of relationship with suppliers in years +1 .

(4) As opposed to late or non delivery.

(5) Some recourse to one of the following: private arbitration; police; lawyers; courts.

Threats of recourse to police and courts are included. 
Table 10. Logit Regressions on Settlement of Contractual Disputes With Clients

(Robust standard errors reported using country-level clustering)

\begin{tabular}{|c|c|c|c|c|c|c|}
\hline \multirow[b]{2}{*}{ Location dummies (1) } & \multicolumn{2}{|c|}{$\begin{array}{l}\text { Dispute } \\
\text { settled }\end{array}$} & \multicolumn{2}{|c|}{$\begin{array}{c}\text { Settlement } \\
\text { satisfactory (6) }\end{array}$} & \multicolumn{2}{|c|}{$\begin{array}{l}\text { Trade relation } \\
\text { continues }\end{array}$} \\
\hline & Odds ratio & z stat. & dds ratio & z stat. & dds ratio & z stat. \\
\hline Kenya & 0.771 & -0.412 & 3.760 & 3.051 & 0.616 & -0.909 \\
\hline Cameroon & 0.122 & -9.721 & 0.551 & -1.233 & 0.728 & -0.553 \\
\hline Cote d'Ivoire & 0.495 & -0.765 & 0.886 & -0.185 & 0.482 & -0.845 \\
\hline Burundi & 0.384 & -1.525 & 0.247 & -1.723 & 1.657 & 0.715 \\
\hline Zambia & 1.415 & 0.602 & 2.760 & 2.452 & & \\
\hline Main city & 0.812 & -0.612 & 2.044 & 0.652 & 0.878 & -0.426 \\
\hline Secondary city & 0.711 & -1.027 & 0.778 & -0.178 & 0.585 & -1.309 \\
\hline \multicolumn{7}{|l|}{ Sectoral dummies: } \\
\hline Textile & 0.498 & -1.742 & 0.458 & -1.257 & 1.100 & 0.181 \\
\hline Metal & 0.210 & -11.369 & 0.263 & -1.842 & 0.865 & -0.728 \\
\hline Wood & 0.443 & -1.957 & 0.461 & -1.967 & 0.937 & -0.155 \\
\hline Average incidence of problems: & 13.319 & 1.083 & 392.868 & 2.719 & 1.804 & 0.356 \\
\hline \multicolumn{7}{|l|}{ Firm characteristics: } \\
\hline Size (2) & 1.256 & 1.600 & 0.668 & -2.142 & 1.017 & 0.248 \\
\hline Age (3) & 1.469 & 1.163 & 1.963 & 1.300 & 0.837 & -0.576 \\
\hline Limited liability status & 1.151 & 0.402 & 2.208 & 0.811 & 0.989 & -0.031 \\
\hline Some state ownership & 0.761 & -0.467 & 5.607 & 2.015 & 3.178 & 1.143 \\
\hline Some foreign ownership & 0.971 & -0.152 & 2.489 & 3.271 & 1.121 & 0.186 \\
\hline African owner/manager & 2.733 & 2.279 & 5.964 & 2.318 & 0.609 & -0.938 \\
\hline European owner/manager & 1.098 & 0.229 & 0.633 & -0.585 & 0.421 & -1.748 \\
\hline \multicolumn{7}{|l|}{ Relationship with clients: } \\
\hline Sell to manufacturers/consumers & 1.803 & 1.071 & 1.324 & 0.518 & 2.564 & 2.139 \\
\hline Sell to public firms & 0.489 & -4.141 & 1.215 & 0.223 & 0.463 & -3.007 \\
\hline Share of exports in sales & 0.850 & -0.253 & 3.569 & 1.734 & 1.846 & 0.611 \\
\hline \multicolumn{7}{|l|}{ Characteristics of problematic client: } \\
\hline Individual & 0.409 & -2.374 & 0.526 & -0.730 & 1.047 & 0.097 \\
\hline Relative or same ethnicity & 2.605 & 2.518 & 0.750 & -0.351 & 0.875 & -0.400 \\
\hline Length of relationship (4) & 0.879 & -0.658 & 0.643 & -2.123 & 1.452 & 1.230 \\
\hline Dispute is about non-payment (5): & 0.173 & -4.548 & 0.129 & -3.681 & 0.179 & -11.847 \\
\hline \multicolumn{7}{|l|}{ Conflict resolution method: } \\
\hline Direct negociations & 2.510 & 6.401 & 0.400 & -2.433 & 1.433 & 1.654 \\
\hline Private arbitration & 2.725 & 1.794 & 0.884 & -0.102 & 0.761 & -0.282 \\
\hline Police & 0.306 & -2.052 & 1.049 & 0.028 & 0.385 & -2.473 \\
\hline Lawyers and courts & 0.711 & -1.205 & 0.369 & -2.441 & 0.263 & -5.731 \\
\hline Number of observations & 358 & & 184 & & 279 & \\
\hline Pseudo R-squared & 0.270 & & 0.269 & & 0.255 & \\
\hline Correctly classified & $78 \%$ & & $85 \%$ & & $76 \%$ & \\
\hline
\end{tabular}

(1) Zimbabwe is the omitted country; small town is the omitted city category.

(2) Firm size $=\log$ (number of employees +1 ); (3) Firm age = log(1995 - year of inception).

(4) Length of relationship $=\log$ (years of acquaintance with problematic client +1 ).

(5) As opposed to late payment.

(6) Conditional on the dispute being settled. 
Table 11. Logit Regressions on Settlement of Contractual Disputes With Suppliers

(Robust standard errors reported using country-level clustering)

\begin{tabular}{|c|c|c|c|c|}
\hline \multirow[b]{2}{*}{ Location dummies (1) } & \multicolumn{2}{|c|}{ Dispute settled } & \multicolumn{2}{|c|}{ continues } \\
\hline & Odds ratio & z stat. & dds ratio & z stat. \\
\hline Kenya & n.a. & n.a. & 0.222 & -1.441 \\
\hline Cameroon & 2.139 & 1.034 & n.a. & n.a. \\
\hline Ivory-Coast & 3.126 & 1.822 & 195.856 & 3.229 \\
\hline Burundi & 4.476 & 1.637 & 177.637 & 2.894 \\
\hline Zambia & 1.191 & 0.563 & n.a. & n.a. \\
\hline Main city & 0.483 & -1.708 & 1.542 & 1.469 \\
\hline Secondary city & 0.797 & -0.805 & 1.679 & 1.301 \\
\hline \multicolumn{5}{|l|}{ Sectoral dummies: } \\
\hline Textile & 2.581 & 2.582 & 1.674 & 2.425 \\
\hline Metal & 1.581 & 1.313 & 1.688 & 1.190 \\
\hline Wood & 1.678 & 0.885 & 0.646 & -0.713 \\
\hline Average incidence of problems: & 19.941 & 3.402 & $2 \mathrm{E}+07$ & 3.048 \\
\hline \multicolumn{5}{|l|}{ Firm characteristics: } \\
\hline Size (2) & 0.961 & -0.172 & 1.125 & 3.796 \\
\hline Age (3) & 0.703 & -1.573 & 1.919 & 3.249 \\
\hline Limited liability status & 0.842 & -0.373 & 1.340 & 0.458 \\
\hline Some state ownership & 8.845 & 1.497 & 0.728 & -0.660 \\
\hline Some foreign ownership & 0.742 & -0.431 & 0.970 & -0.139 \\
\hline African owner/manager & 0.732 & -0.252 & 1.833 & 1.804 \\
\hline European owner/manager & 0.927 & -0.086 & 0.919 & -0.166 \\
\hline \multicolumn{5}{|l|}{ Relationship with suppliers: } \\
\hline One supplier monopolistic & 0.844 & -0.688 & 3.088 & 1.686 \\
\hline One supplier public firm & 1.532 & 1.789 & 1.702 & 3.466 \\
\hline Share of imported inputs & 1.005 & 0.899 & 0.995 & -2.413 \\
\hline$\%$ purchases from main supplier & 1.001 & 0.090 & 1.005 & 1.312 \\
\hline Length of relationship (4) & 1.404 & 1.854 & 1.142 & 0.575 \\
\hline One supplier friend or family & 0.575 & -0.915 & 0.222 & -2.529 \\
\hline Dummy for infrequent purchases & 0.385 & -4.357 & 0.676 & -1.702 \\
\hline Receives supplier credit & 0.934 & -0.125 & 2.606 & 6.124 \\
\hline Gives advance payment & 3.052 & 1.356 & 0.863 & -0.183 \\
\hline \multicolumn{5}{|l|}{ Characteristics of problematic supplier: } \\
\hline Dummy if first time supplier & 0.482 & -0.910 & 0.182 & -0.950 \\
\hline Length of relationship (4) & 1.076 & 0.343 & 0.382 & -2.185 \\
\hline Dummy if public firm & 0.214 & -6.455 & 0.717 & -0.988 \\
\hline individual & 1.110 & 0.179 & 2.213 & 1.241 \\
\hline Dispute about deficient quality (5): & 0.911 & -0.266 & 0.926 & -0.417 \\
\hline \multicolumn{5}{|l|}{ Conflict resolution method: } \\
\hline Direct negociations & 4.335 & 13.105 & \multicolumn{2}{|c|}{ not included (6) } \\
\hline Use of legal institutions & 2.283 & 1.289 & \multicolumn{2}{|c|}{ not included (6) } \\
\hline Numbe & 262 & \multicolumn{3}{|c|}{230} \\
\hline Pseudo R-squared & 0.182 & \multicolumn{3}{|c|}{0.254} \\
\hline Correctly classified & $76 \%$ & \multicolumn{3}{|c|}{$83 \%$} \\
\hline
\end{tabular}

Trade relationship continues

(1) Firm size $=\log$ (number of employees +1 ); (2) Firm age $=\log (1995-$ year of inception).

(3) Log of average length of relationship with suppliers in years +1 .

(4) Length of relationship $=\log$ (years of acquaintance with problematic client +1 ).

(5) As opposed to late or non delivery.

(6) These variables could not be included in the regression due to insufficient number of observations. 